\title{
Systematic Revision of the Epipetrum Group of Dioscorea (Dioscoreaceae) Endemic to Chile
}

\author{
Juan Viruel, ${ }^{1}$ José G. Segarra-Moragues, ${ }^{2,4}$ Ernesto Pérez-Collazos, ${ }^{1}$ Luis Villar, ${ }^{3}$ and Pilar Catalán \\ ${ }^{1}$ Departamento de Agricultura y Economía Agraria, Escuela Politécnica Superior de Huesca, \\ Universidad de Zaragoza, C/ Carretera de Cuarte Km 1, E-22071 Huesca, Spain \\ ${ }^{2}$ ARAID-UZ. Departamento de Agricultura y Economía Agraria, Escuela Politécnica Superior de Huesca, \\ Universidad de Zaragoza, C/ Carretera de Cuarte Km 1, E-22071 Huesca, Spain \\ ${ }^{3}$ Departamento de Ecología funcional y Biodiversidad. Instituto Pirenaico de Ecología. Consejo \\ Superior de Investigaciones Científicas (CSIC) Apdo. 64. E-22700 Jaca, (Huesca), Spain \\ ${ }^{4}$ Author for Correspondence (jogasemo@unizar.es) \\ Communicating Editor: Gregory M. Plunkett
}

\begin{abstract}
A systematic revision of the Epipetrum group of Dioscorea (Dioscoreaceae), which traditionally included three taxa endemic to Chile, is presented. We evaluated the taxonomic value of macro- and micromorphological traits to delimit generic boundaries with respect to other yams and to identify and separate its taxa. The comprehensive survey included 10 qualitative and 43 quantitative traits related to all plant organs and new microanatomical features of leaf, fruits, seeds, and pollen. Discriminant analyses were conducted with three accumulative morphological data sets to test seven taxonomic hypotheses of differentiation among taxa. Our results indicate that these taxa are characterized by the combination of prominent pistillodes in male flowers and a base chromosome number of $x=7$, which separate it from all other Dioscoreaceae, plus different sets of morpho-anatomical traits that differentiate it from other putatively closely related yams with unwinged seeds in Dioscorea (the Borderea group, the Nanarepenta group, the Tamus group, etc.). Dioscorea biloba is the most distinctive species. Our analyses revealed significant morphological differences between northern and southern populations of this species resulting in the recognition of two subspecies, the northern D. biloba subsp. biloba, and the new southern D. biloba subsp. coquimbana. Dioscorea humilis and D. polyanthes are morphologically similar and only differ in qualitative leaf traits. This minor variation is better treated by reducing $D$. polyanthes to subspecific rank in D. humilis, and the combination $D$. humilis subsp. polyanthes is made herein.
\end{abstract}

Keywords—Discriminant analysis, morphology, pollen, SEM, South America, taxonomy.

Epipetrum Phil. has long been considered one of the five narrow genera of Dioscoreaceae, comprising only three species endemic to Chile (Knuth 1924; Burkill 1960). Specimens of the most common species of this genus, collected by Bertero (1829) from Central Chile, were first described as Luzuriaga cordata Bertero, although the plant does not show any morphological affinities with the members of this unrelated genus of Philesiaceae. This misinterpretation was noticed by Colla (1836) who redescribed the species as Dioscorea humilis Colla, creating a nomenclatural conflict that has been recently clarified (Viruel et al. 2009). Dioscorea humilis was later transferred to a new genus, Epipetrum [E. humile (Colla) Phil.] by Philippi (1862) after the rupicolous habitat of the plant. According to Philippi $(1862,1864)$, the separation of this new genus from Dioscorea L. was justified by the absence of winged seeds. This remarkable trait is also shared with three other small genera of the yam family: the Mediterranean-Macaronesian Tamus L., which posseses a baccate fruit rather than a capsule (as in almost all other Dioscorea s. 1. species), the Pyrenean Borderea Miégeville, and the Mexican Nanarepenta Matuda (Matuda 1961; Téllez-Valdés and Dávila-Aranda 1998), African Dioscorea gilletii Milne-Redh. (Milne-Redhead 1963), Caribbean Rajania L., and some other Dioscorea species with samaroid fruits. The combination of unwinged seeds produced in three-angled capsules, and a dwarf trailing habit shared with Borderea, led Pax (1887) to place E. humile within Borderea [B. humilis (Bertero ex Colla) Pax], a classification later criticised based on morphological and biogeographical studies of Dioscoreaceae (Reiche 1908; Burkill 1960). None of the preceding nomenclatural combinations took into account the original and validly published specific epithet of this plant as L. cordata, and thus this epithet became substituted in the literature by the currently accepted one (humile), forcing the rejection of cordata to promote nomenclatural stability (Viruel et al. 2009).

Despite the low taxonomic diversity within Epipetrum, the boundaries among some of its taxa are not completely clear.
Three decades after the description of L. cordata (E. humile), Philippi (1892) described an additional species that he collected from northern Chile (Antofagasta, Region II) and named E. bilobum Phil. after its strongly bilobed leaves. Almost simultaneously, Reiche collected some individuals of Epipetrum from south-central Chile (near Constitución, Maule, Region VI), which resembled E. humile in overall gross morphology. Nonetheless, a careful inspection of the specimens by Philippi (1896) resulted in the description of a third species, E. polyanthes F. Phil., which differed from typical E. humile by its fleshier leaves lacking marked secondary venation. Nevertheless, the fruits and seeds of the two new species remained undescribed.

A later revision of Epipetrum with comparison to Borderea revealed the morphological differences between the genera (Reiche 1908). Despite the thorough revision of Reiche (1908), the differences between E. humile and E. polyanthes were not adequately translated into the identification key and did not agree with observations made by Philippi (1896).

As mentioned above, the taxonomic identity of this poorly known genus has been controversial, as different authors have either synonymized it under other genera of Dioscoreaceae (Colla 1836; Pax 1887; Caddick et al. 2002a, b) or have treated it as an independent genus (Philippi 1862, 1864; Reiche 1908; Knuth 1924). Recent phylogenetic studies, with a broader perspective of Dioscoreaceae and based on morphological and molecular data, placed the wingless-seeded genera (Borderea, Epipetrum, Nanarepenta, and Tamus) as nested within a large paraphyletic Dioscorea clade (Caddick et al. 2002a), and subsequently subsumed them within Dioscorea (Caddick et al. 2002b). The pan-Mediterranean Tamus and the Pyrenaean Borderea were placed as sister taxa within a weakly supported African Dioscorea clade in trees based on plastid $r b c L$ (Caddick et al. 2002a) and combined rbcL-matK plastid data (Wilkin et al. 2005). However, the apparent close relationships of Epipetrum to Borderea and Tamus were inferred solely based 
on morphological characters, since no molecular data were obtained for Epipetrum (Caddick et al. 2002a, b). The phylogenetic relationships of Epipetrum to other taxa of the family Dioscoreaceae requires confirmation from molecular data. However, a preliminary analysis indicates that Epipetrum emerges as a monophyletic group embedded within a South American clade of Dioscorea (Viruel et al. unpublished data), supporting the findings of Caddick et al. (2002a, b) and the reassessment of Epipetrum within Dioscorea (Caddick et al. 2002b). Therefore, we hereafter treat Epipetrum as a species group in Dioscorea.

Additional samples of these Epipetrum taxa collected in the early to middle 1900s provided more data on their geographical distribution (Fig. 1). The most common species, Dioscorea humilis, is presently known from five areas in central Chile (from central Valparaíso to southern Bío-Bío). The known range of $D$. polyanthes has remained unchanged and is restricted to the area around the type locality at Constitución (Maule region), whereas for D. biloba, in addition to the northern locality in Antofagasta, a disjunct southern population was found in the Limarí province (Coquimbo region) in 1948. The southern population of D. biloba has not been found recently and consequently the species was assessed as insufficiently known and presumed extinct (Marticorena et al. 2001). Surprisingly, none of these three species were included in the catalogue of threatened plant species from central-southern Chile (Hechenleitner et al. 2005) but were included in the Millennium Seed Bank Project led by the Chilean Instituto de Investigaciones Agropecuarias (INIA) and the Royal Botanic Gardens, Kew.

Historical collections of the Epipetrum group have been scarce, precluding any detailed study of their morphological variation. Given that most of the available data for these three species comes from their original descriptions, with few updates, we have undertaken a systematic revision of the genus based on newly collected specimens and an exhaustive morphological study. Statistical methods widely used in plant systematics (Baum 1989; Torrecilla et al. 2003; Pimentel and Sahuquillo 2007) have also been incorporated in the analysis as a suitable approach for detecting significant differences among taxa. Specifically, our study is aimed at (i) conducting a thorough survey of macro- and micromorphological traits that would reveal the extent of morphological differences among the three taxa, with special emphasis on the most similar, $D$. humilis and D. polyanthes; (ii) analyzing the extent of morphological differentiation between disjunct areas of $D$. biloba; (iii) assigning populations and individuals to predefined groups based on discriminant analyses; (iv) comparing the morphological similarities and differences with other natural groups in Dioscorea, with special reference to the wingless-seeded species; (v) providing updated geographical distributions and habitat descriptions for each taxon; and (vi) supplying detailed illustrations showing the distinctive characters of each species.

\section{Materials ANd Methods}

Sampled Materials-Due to the scarcity of herbarium specimens from the Epipetrum group in both Chile (SGO, CONC) and internationally (B, G, K, MO, NY, SI, TO), two expeditions were organized to Chile from which abundant materials were collected for the three taxa. Samples were collected from a total of 25 populations, including 14 populations of D. humilis covering the entire distributional range of the species, nine populations of D. biloba, six corresponding to the southern range and three to the northern range for this species, and two populations of the rarest species, D. polyanthes (Fig. 1). High resolution scans of the type specimens of the three species were obtained from G, SGO, and TO.

Analysis of Macromorphological Traits-Measurements of macromorphological traits were taken from the new collections deposited at JACA. A total of 53 morphological characters (43 quantitative and 10 qualitative characters; Table 1) were measured from 188 plants, including 79 individuals of D. biloba, 99 of D. humilis, and 10 of D. polyanthes (from 32, 32, and three herbarium vouchers, respectively; see representative material examined) using an SM7800 stereomicroscope and a micrometer to the nearest $0.05 \mathrm{~mm}$. Eight plants were excluded because they were incomplete

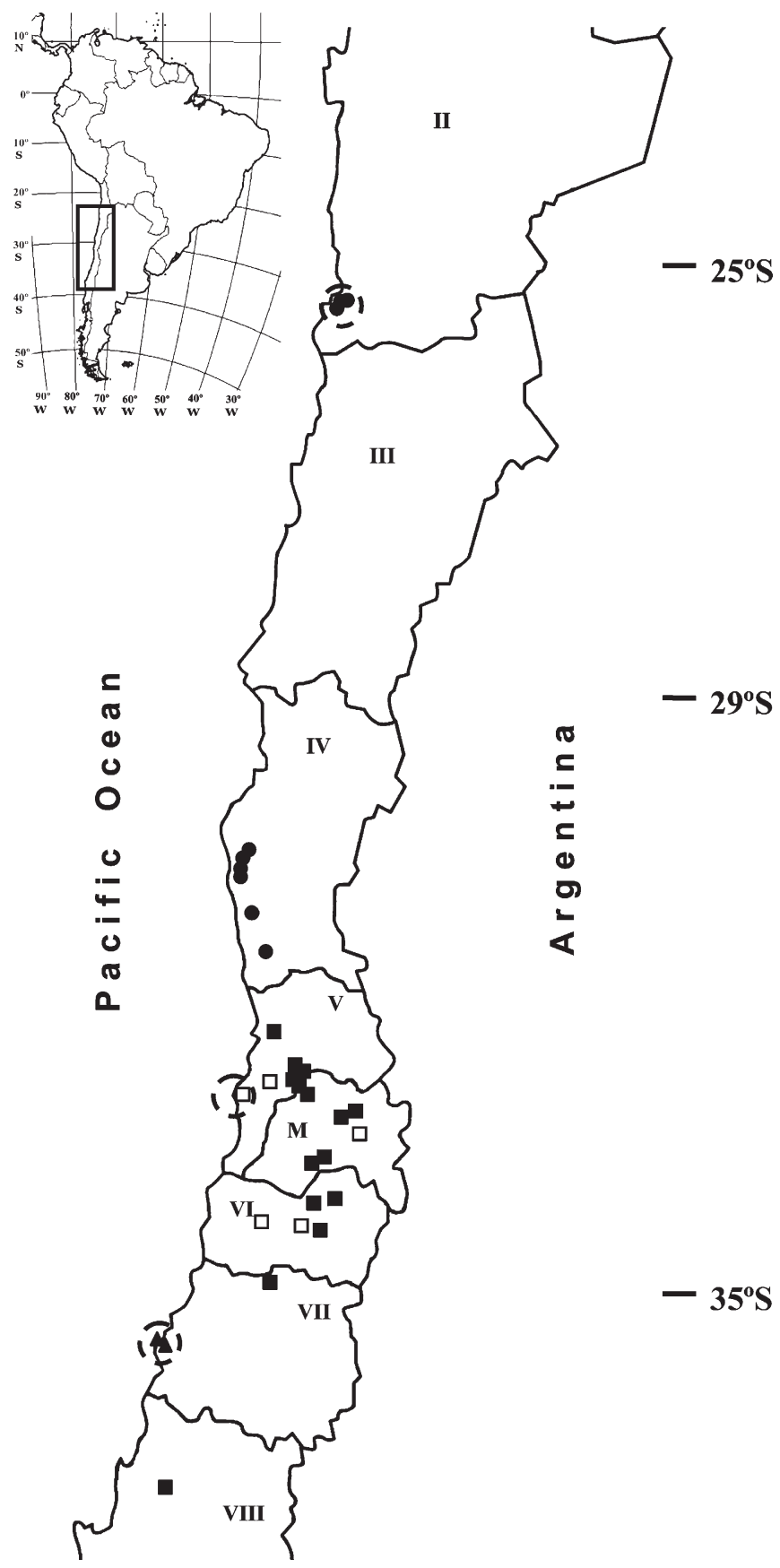

FIG. 1. Geographical distributions of the Epipetrum group of Dioscorea taxa in Chile. Dioscorea biloba (circles), D. humilis (squares), D. polyanthes (triangles). Filled symbols represent new collections from this study, white symbols represent additional historical records taken from both old herbarium specimens and the literature where different from our sampled sites. Dashed lines encircle the type locality of each taxon. Roman numbers denote Chilean administrative regions: II-Antofagasta, IIIAtacama, IV-Coquimbo, V-Valparaíso, M-Metropolitan region of Santiago, VI-O'Higgins, VII-Maule and VIII-Bío-Bío. 
TABLE 1. List of quantitative and qualitative morphological traits studied in the Epipetrum group of Dioscoera and their abbreviations. Measurement units of quantitative characters are expressed in parentheses. Character-states are specified for the qualitative characters.

Quantitative characters (43). $\mathrm{tl}$ - Tuber length $(\mathrm{cm})$. tw - Tuber width $(\mathrm{cm})$. sml - Shoot maximum length (cm). fbp - Distance from the tuber to the first branching point $(\mathrm{cm})$. li - Length of internodes $(\mathrm{cm})$. stw - Shoot width at the base $(\mathrm{mm})$. $\mathbf{n b}$ - Number of branches at fbp. nlsn - Number of leaves at shoot nodes. pl - Petiole length (mm). nln - Number of veins per leaf. lpn - Length of primary vein (mm). 11 - Maximum leaf length (mm). $1 \mathbf{w}$ Maximum leaf width $(\mathrm{mm})$. 1lb - Length of longest lobe of leaf $(\mathrm{mm})$. wwb - Width of widest lobe of leaf $(\mathrm{mm})$. lsb - Length of shortest lobe of leaf $(\mathrm{mm})$. wnb - Width of narrowest lobe of leaf $(\mathrm{mm})$. 1lb/lsb - llb and lsb ratio. wwb/wnb - wwb and wnb ratio. $1 \mathrm{~m}$ - Length of mucro (mm). $1 \mathrm{mi}$ - Length of male inflorescence $(\mathrm{cm})$. $\mathbf{n f m}$ - Number of flowers in male inflorescence. bl - Bract length ( $\mathrm{mm})$. lmped - Length of pedicel of male flower (mm). tlm - Tepal length of male flower (mm). twm - Tepal width of male flower $(\mathrm{mm})$. tsl - Total stamen length (mm). fsl - Length of filament of stamen (mm). sal - Anther length (mm). lmp - Length of pistillodes of male flower $(\mathrm{mm})$. lfi - Length of female inflorescence $(\mathrm{cm})$. nff - Number of flowers in female inflorescence. lfped - Length of pedicel of female flower (mm). tlf - Tepal length of female flower $(\mathrm{mm})$. ls - Length of style (mm). lo - Length of ovary (mm). cl - Maximum length of capsule (mm). cw - Maximum width of capsule (mm). lpd - Length of peduncle (mm). fcl - Length of persistent tepals $(\mathrm{mm})$. sl - Maximum length of seed (mm). sw - Maximum width of seed (mm). scl - Length of seed caruncle (mm).

Qualitative characters (10). pt - Phyllotaxis: 0, alternate; 1, opposite; 2, whorled. lo - Leaf outline: 0, obcordate; 1, bilobed. Inerv - Leaf venation: 0, not prominent; 1, promnent. lmar - Leaf margin: 0 , entire, 1, wavy, 2, slightly toothed. lc - Adaxial and abaxial leaf color: 0 , same; 1 , abaxial darker. clp Color of papillae: 0 , colorless; 1 , colored. tdisp - Tepal: 0 , patent; 1 , horizontal; 2 , squarrose. sp - Shape of peduncle: 0 , strait, 1 spirally curled. fs - Fruit shape: 0 , obovoid; 1 , globose. ccol - Color of capsule: 0 , light green; 1 , dark green.

for the characters studied. Vegetative characters were studied in all 181 individuals whereas floral and/or fruit characters were scored from a subset of 120 mature individuals. For each individual, ten measurements per character were taken and the averages were calculated for the multivariate analysis.

Scanning Electron Microscopy Analysis-Mature leaves and capsules were dehydrated in increasing ethanol series and critical-point dried using carbon dioxide in an AUTOSAMDRI 840 (Tousimis) and mounted afterwards on stubs for gold/palladium coating. Mature pollen and seeds were mounted directly on stubs using double-sided adhesive tape and coated with gold/palladium in a BIORAD SC-500 ion sputtering coater. Morphological observations were carried out in a Hitachi S-4100 field emission scanning electron microscopy (SEM). Nomenclature for pollen characters follows Caddick et al. (1998) and Schols et al. (2001, 2003, 2005).

Statistical Analyses-Statistical analyses were aimed at revealing whether morphological variation was consistent with currently recognized species within the Epipetrum group and identifying the most informative morphological characters for the differentiation of the taxa. A ShapiroWilk test (Shapiro and Wilk 1965) was used to check for departures of quantitative characters from a normal distribution to exclude them from further analyses. Five out of 43 quantitative characters ( $t l, t w, s m l, n f m$, and lfped; Table 1) were not continuous within individual taxa and were excluded from the analysis. We conducted a classification discriminant analysis (DA) using SPSS for Windows v. 15 (SPSS Inc., Chicago, Illinois). This method calculates the probabilities of membership of each OTU to the taxonomically predefined groups (D. humilis, D. biloba, and D. polyanthes, and different combinations of them), allowing the identification of the more discriminant variables by means of Fisher's coefficient (Fisher 1936; Anderson 1996) at the significant threshold value of 0.05. In subsequent analyses, both invariant and nonsignificant (Fisher's test $p$ value $>$ 0.05 ) variables for the corresponding analyzed groups of samples were excluded. The number of informative morphological characters varied from six to 16, depending on the group of samples analysed each time. Seven different hypothetical classifications were tested to identify the different taxonomic units: (1) D. humilis versus D. polyanthes; (2) D. biloba versus $D$. humilis; (3) northern $D$. biloba versus southern $D$. biloba; (4) D. biloba versus $D$. humilis versus $D$. polyanthes; (5) D. biloba versus $D$. humilis with D. polyanthes assignment not predefined; (6) D. biloba versus D. humilis + D. polyanthes; (7) northern D. biloba versus southern $D$. biloba versus $D$. humilis versus $D$. polyanthes. The posterior probability of classification of each sample and the Wilks' Lambda value of each discriminant function and sampled group considered were calculated (Wilks 1932). The Wilks' Lambda value expresses the proportion of total variability between predefined groups allowing the contrast of the null hypothesis of equality of multivariant average of groups or centroids (Visanta-Vinacua 1998). As the value of Wilks' Lambda approaches zero, the discrimination between the predefined groups is better. Analyses were conducted using three different subsets of morphological characters, including quantitative stem and leaf traits, quantitative and qualitative stem and leaf traits, and combined datasets of quantitative and qualitative traits of stem, leaves, and fruits.

\section{RESUlts}

Morphological Characters and their Taxonomic Importance in the Systematics of the Epipetrum group of Dioscorea-All plant organs were investigated in the search for potentially taxonomically valuable characters. These included both macroscopic (Table 1) and microscopic (SEM) features (Figs. 2-6). Species of the Epipetrum group showed a high overall similarity in gross morphological traits, especially the species pair $D$. humilis- $D$. polyanthes. Little variation was found within these two species, but unexpectedly higher differentiation was found between northern and southern populations of D. biloba. Morphological variation was mostly related to vegetative characters, especially leaf features, but differences were also observed for some fruit traits. A summary of the range and mean values of the analyzed quantitative traits and the character states of qualitative traits studied in these species is presented in Table 2.

Tubers - All three Dioscorea species exhibited similar values for both quantitative and qualitative morphological traits derived from tubers. In these taxa, dark brown tubers are totally covered by roots and show an irregular, sometimes branched, to globose shape. Because of the lack of infrageneric variability, the traits derived from tubers ( $t l, t w$, color) were of little value for species differentiation (Tables 1, 2).

STEM-Each year the plants produce a single, slender (up to $4 \mathrm{~mm}$ in diam.), tetragonous aerial stem that divides into as many as 9 branches at the first branching point. The distance from the base to the branching point seems to depend on the depth at which the tuber is buried and therefore this character has no taxonomic value (Table 2).

LEAVES-Most of the morphological differences found among this group of Dioscorea taxa occur in leaf characters (Figs. 2 and 3). Leaves are petiolate in the three species, but they are whorled (three-14 per node) in D. biloba, alternate in $D$. polyanthes, and alternate, opposite or more rarely whorled (up to six per node, in the population of Catapilco, Region V) in D. humilis. Leaves of $D$. biloba are wider than they are long and strongly bilobed, in contrast to those of D. humilis and $D$. polyanthes which are obovate with a weakly emarginate apex. The leaf texture is membranous in D. biloba and $D$. humilis, but somewhat fleshy in D. polyanthes. All taxa have mucronate leaves, with entire to slightly papillose-crenulate margins in older leaves. Primary venation is inconspicuous in D. biloba (Figs. 2A, B, D, E), but strongly conspicuous (with three to seven primary veins) in $D$. humilis and D. polyanthes (Figs. $2 \mathrm{G}, \mathrm{H}, \mathrm{J}, \mathrm{K})$. Secondary venation is prominent in $D$. humilis giving the leaves a grooved texture, a character unique to this taxon (Figs. 2G, H), while it is almost undetectable in D. biloba (Figs. 2A, B, D, E) and D. polyanthes (Figs. 2J, K), giving the 


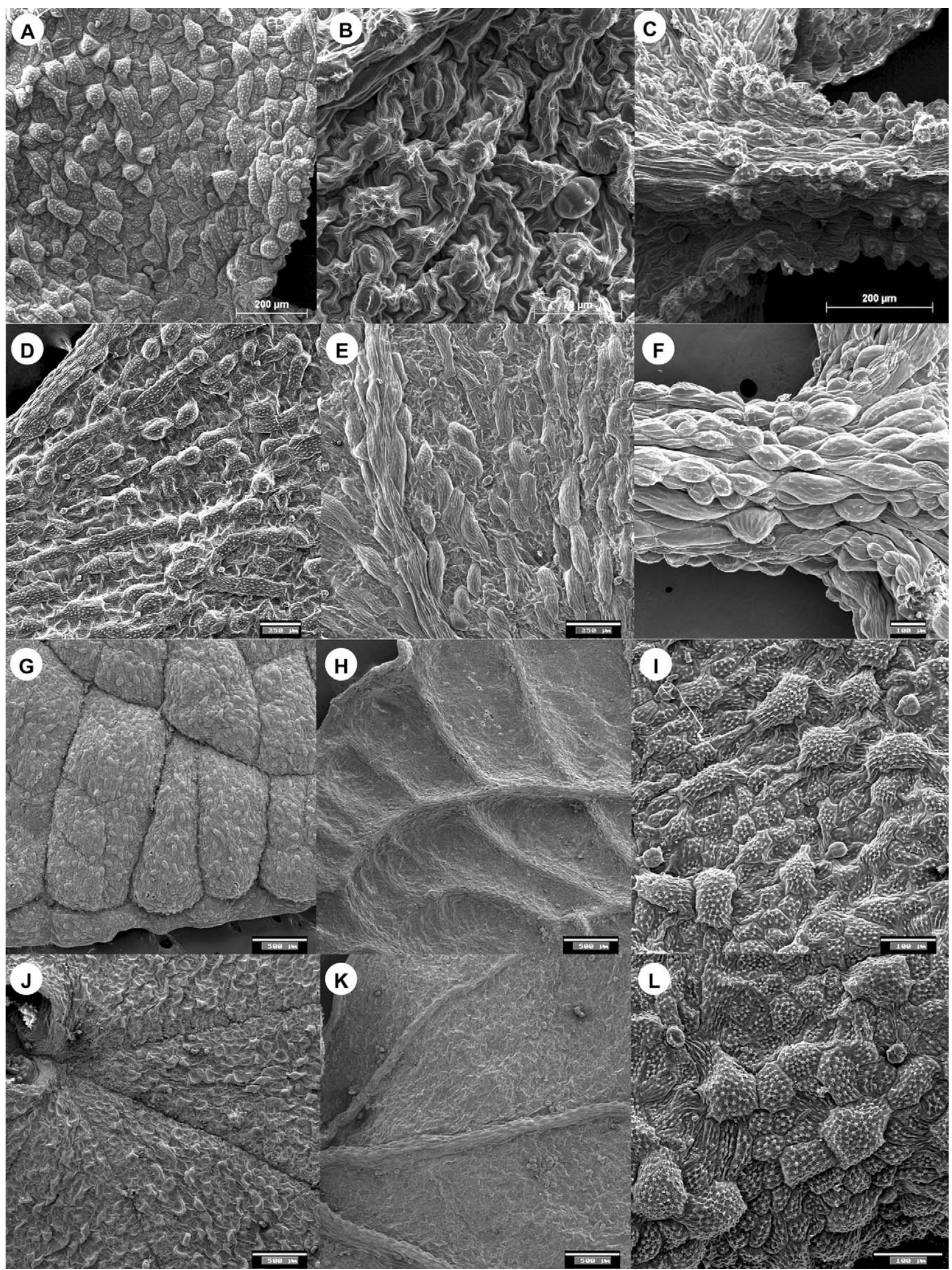

Fig. 2. Scanning electron microscopy photographs of leaves of the Epipetrum group of Dioscorea species. A-C. Northern D. biloba. D-F. Southern D. biloba. G-I. D. humilis. J-L. D. polyanthes. A, D, G, J. General view of adaxial side. B, E, H, K. General view of abaxial side. C, F, I, L. General view of epidermis showing flat epidermal cells and bulging papillae (C, F. Abaxial side; I, L. Adaxial side). Scale bars: G, H, J, K, $500 \mu \mathrm{m}$; D, E, $250 \mu$ m; A, C, $200 \mu$ m; F, I, L, 100 m; B, 70 m. (A-C, from R284621, JACA; D-F, from R282247, JACA; G-I, from R282269, JACA; J-L, from R282231, JACA). 


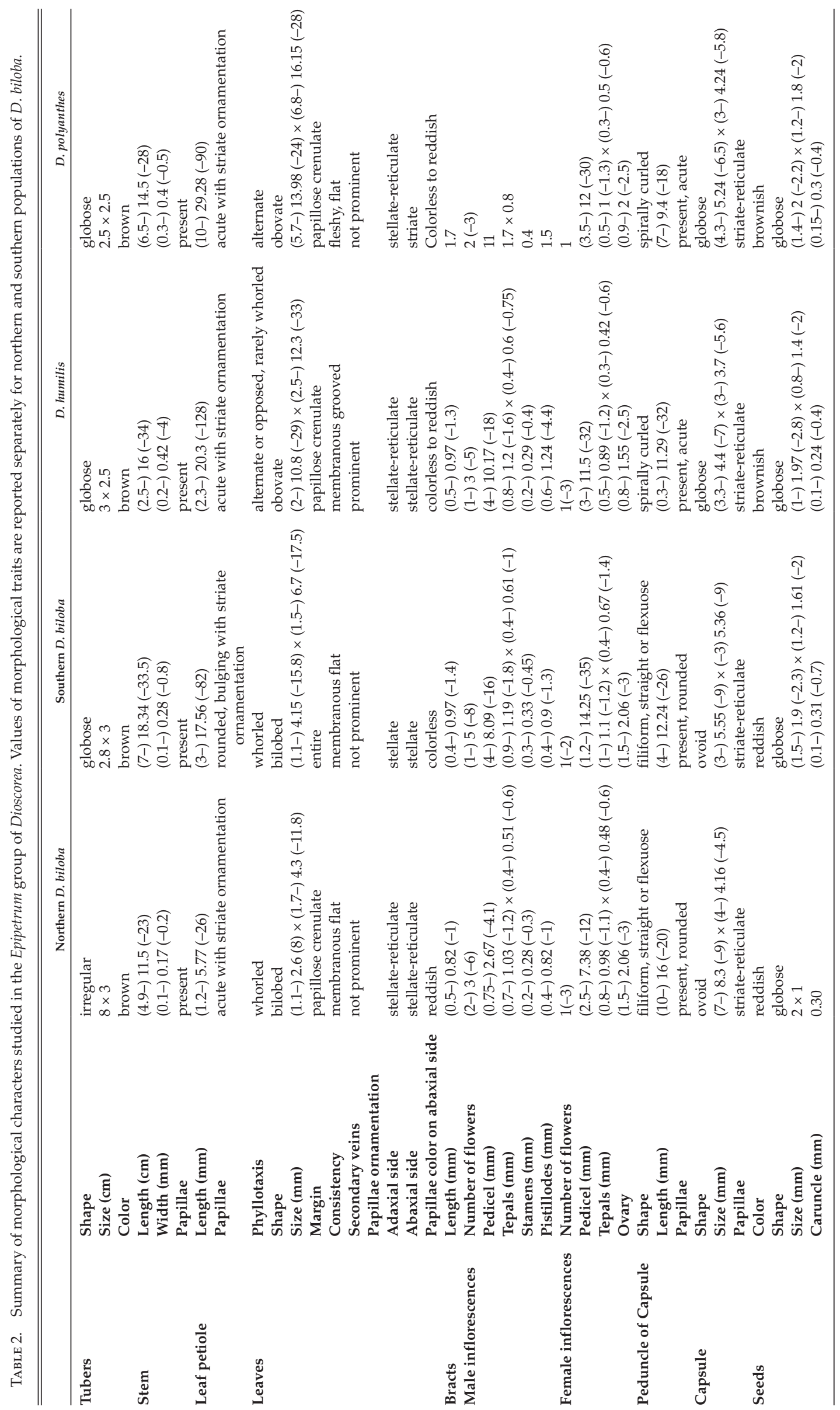


leaves a flat appearance. The pattern is reticulate in all three taxa. All parts of the leaves, including petioles, are covered by small glandular hairs and papillae in each of the three taxa (Figs. 2A-C, F, I, L, 3). The glandular hairs of these taxa are composed of a one-celled stalk and a gland of up to six cells. Due to their size $(5 \mu \mathrm{m})$, these glands were previously only visible in histological preparations (Reiche 1908); here we present SEM observations at much greater resolution (Figs. 2I, L, 3N). The papillae in the Epipetrum group (Figs. 2A-C, F, I, L, 3) consist of enlarged and bulging epidermal cells. They are colorless on the adaxial side of leaves of all taxa. On the abaxial side, they are colorless in southern populations of $D$. biloba, reddish in northern populations of D. biloba, and colorless to reddish in D. humilis and D. polyanthes. The sculpturing of the periclinal wall of the leaf papillae is stellate-reticulate in both sides of the leaf in northern D. biloba (Figs. 3A-C) and D. humilis (Figs. 3G-I). In southern D. biloba, it is stellate on both sides of the leaf (Figs. 3D, F), and in D. polyanthes, it is stellate-reticulate on the adaxial side (Figs. 3J, L) but striate or smooth on the abaxial side (Fig. 3K). Papillae on the leaf petioles are rounded and strongly bulging in southern $D$. biloba (Figs. 2F, 3M), in contrast to the conical and sharply pointed ones of northern D. biloba, D. humilis, and D. polyanthes (Fig. 3O). In all three taxa, the periclinal walls of the papillae show a striate sculpturing.

INFLORESCENCES - Inflorescences are axillary. Male plants have shortly racemose to cymose inflorescences (occasionally because of suppression of internodes between flowers) that produce up to eight flowers. Those of D. humilis and D. polyanthes are very fragile and ephemeral, falling soon after anthesis, whereas those of $D$. biloba remain attached to the male plant for a longer period. Female inflorescences generally produce a single flower or more rarely two to three flowers, born on a long flexuose pedicel. In most populations of the Epipetrum group, male and female inflorescences are found on separate individuals, and are thus strictly dioecious. Occasionally, however, some monoecious individuals, producing both male and female inflorescences, are found in otherwise dioecious populations of $D$. humilis.

FLOWERS - The flowers are trimerous, pedicellate, and unisexual by reduction. Perianths of male and female flowers are two-whorled and isomerous; they are composed of six greenish tepals. The male flowers are produced on erect and fragile pedicels in D. humilis and D. polyanthes, but in erect and robust ones in D. biloba. Male flowers are hypogynous; the androecium is composed of six subsessile stamens and the gynoecium is reduced to prominent, dark purple, sterile pistillodes, without an ovary. All taxa in the Epipetrum group exhibit bisulcate pollen with a perforate to finely reticulate exine (Fig. 4). Female flowers are epigynous and are generally solitary at the end of long, flexuose pedicels. The androecium of female flowers is reduced to six staminodes. The gynoecium is tricarpellate, with a syncarpic ovary and trifid stigma.

FRUITs - The fruit is a 3-locular capsule, crowned by the persistent perianth (Fig. 5), and dehisces by valves from the apex towards the base. Capsules are supported by long filiform and papillose peduncles, which are straight with rounded papillae in D. biloba (Fig. 5J) but spirally curled with acute papillae in D. humilis and D. polyanthes (Figs. $5 \mathrm{~K}$, L). Capsule shape is obovoid (i.e. wider towards apex) in D. biloba and globose (i.e. wider towards middle) in D. humilis and D. polyanthes. Capsules of all three taxa are triquetrous, with three-angled locules that enclose two seeds each, and have undulate margins (Figs. 5A, D, G). The epidermis of young capsules is papillose and glandulose (Fig. 5B). The glandular hairs are identical to those present in leaves and petioles (Fig. 3N, 5B). The papillae show stellate-reticulate to striate-reticulate periclinal walls (Figs. 5C, E, F, H, I) in the three species.

SEEDS - The seeds of the Epipetrum group are globose to ellipsoid and wingless (Fig. 6). They are reddish-brown in all three taxa. The seeds are relatively small, $(1-2.8 \times 0.8-2 \mathrm{~mm})$, and have a caruncle up to $0.7 \mathrm{~mm}$ long (Figs. 6B, E). The seed coat is smooth with irregularly shaped cells. The cells of the testa show a flat periclinal wall that becomes convex and bulging towards the caruncle (Figs. 6C, F). There is no difference among taxa in the seed characters studied.

Classification Discriminant Analyses-Different subsets of the morphological variables that showed significant values of Fisher's coefficient $(p<0.05)$ were used to conduct the corresponding classification discriminant analyses (DA). These subsets included nine variables of the stem and the leaves with quantitative variation: $s t w, n l s n, p l, n l n, l p n, l l, l w, l l b / l s b$, $l m$; four variables of the leaves with qualitative variation: $p t$, lo, lnerv, $l c$; three variables of the fruits with quantitative variation: $c l, c w$, lpd; and two variables of the fruits with qualitative variation: $s p, f_{s}$ (Table 1). Analyses were performed in three independent and additive series of variables, including quantitative traits of stem and leaves, quantitative and qualitative traits of stems and leaves and quantitative and qualitative traits of stems, leaves, and fruits, respectively. This complete set of variables was considered for DAs of the three taxa and infraspecific subgroups (northern and southern D. biloba populations) of the Epipetrum group. However, for particular species combinations $(D$. humilis versus $D$. polyanthes, $D$. biloba versus $D$. humilis) some of the analyses were not attempted because the variables were either constant or showed nonsignificant $(p>0.05)$ values of Fisher's coefficient (results not shown). The seven following species groups (i.e. taxonomic hypotheses) were tested.

1. Dioscorea humilis versus D. POLYANTHES-The standard classification method for samples resulted in the correct classification of $84.9 \%$ and $80 \%$ of the $D$. humilis and $D$. polyanthes samples to their predefined groups considering quantitative traits of stems and leaves alone. However, all of them showed posterior probabilities lower than 1.0 in the cross-validation test (results not shown). The inclusion of qualitative variables of leaves slightly improved the classification with $97.8 \%$ and $100 \%$ of the samples of D. humilis and D. polyanthes correctly classified, respectively, but 22 samples had posterior probabilities lower than 1.0. The inclusion of fruit characters resulted in $100 \%$ correct classification of samples of $D$. humilis and D. polyanthes, respectively; however, two samples showed posterior probabilities lower than 1.0. Wilks' Lambda values of the discriminant function for the three datasets were $0.731,0.344$, and 0.001 , respectively. The addition of fruit characters did not increase significantly the separation of $D$. humilis and D. polyanthes, indicating the better performance of qualitative characters of leaves and the poor taxonomic value of the fruit characters in the differentiation of these two taxa.

2. DiosCorea BILOBA VERSUs D. HUMILIS-The standard classification method of samples resulted in the correct classification of $100 \%$ of the D. biloba and $98.9 \%$ of the D. humilis samples to their predefined groups considering quantitative traits of 


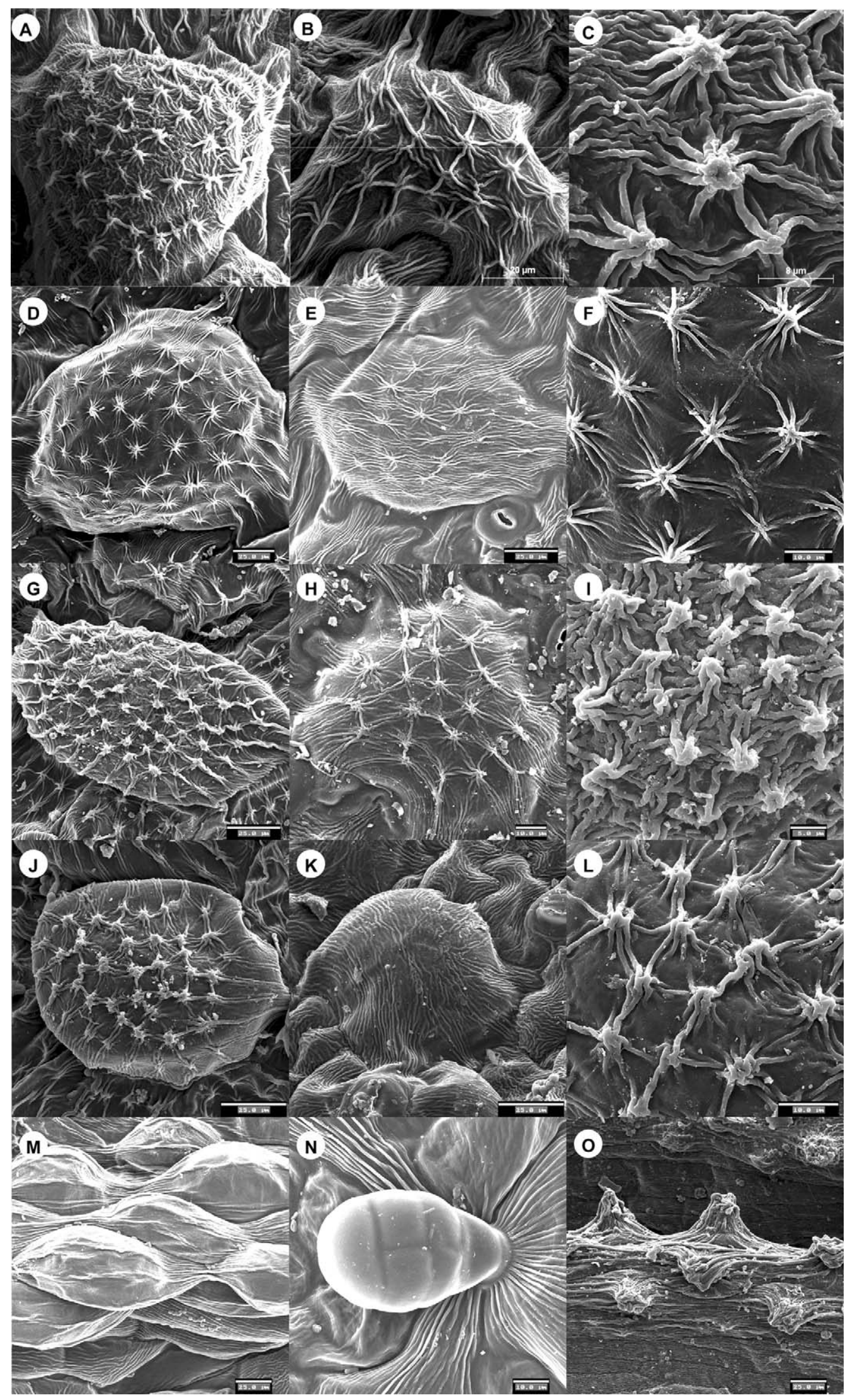

Fig. 3. Scanning electron microscopy photographs of leaves of the Epipetrum group of Dioscorea species. Figs. A-C. Northern D. biloba. D-F, M-N. Southern D. biloba. G-I. D. humilis. J-L, O. D. polyanthes. A, D, G, J. Papillae on the adaxial side, B, E, H, K. Papillae on the abaxial side. C, F, I, L. Details of periclinal cell wall sculpturing of papillae on adaxial side of leaf. M, O. Detail of papillae from petioles. N. Glandular trichome. Scale bars: A, B, $20 \mu \mathrm{m} ; \mathrm{D}$,

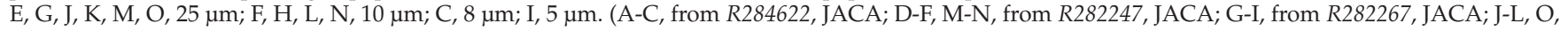
from R282231, JACA). 


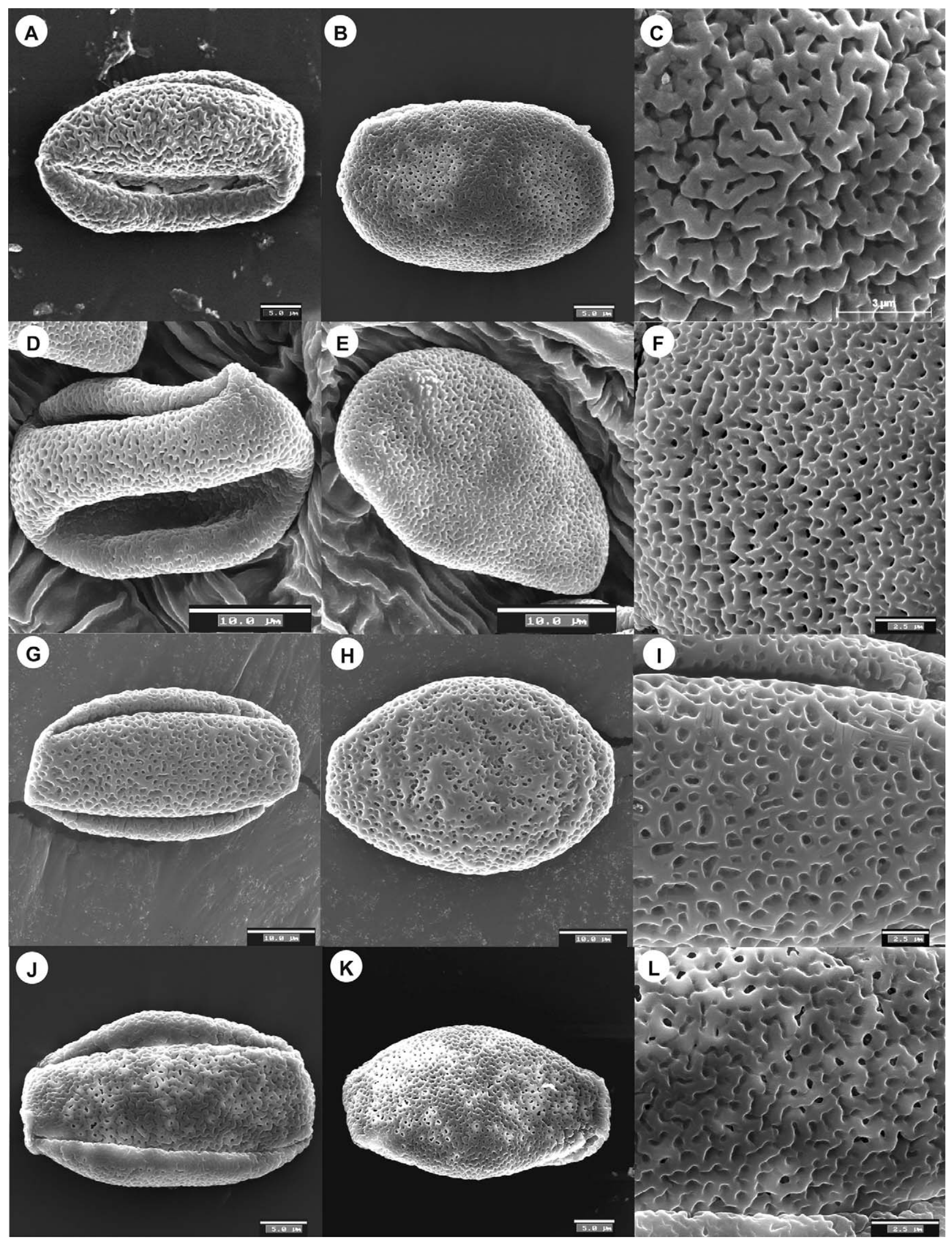

Fig. 4. Scanning electron microscopy photographs of pollen of the Epipetrum group of Dioscorea species. A-C. Northern D. biloba. D-F. Southern D. biloba. G-I. D. humilis. J-L. D. polyanthes. A, D, G, J. Distal polar view. B, E, H, K. Proximal polar view. C, F, I, L. Detail of perforate-finely reticulate exine

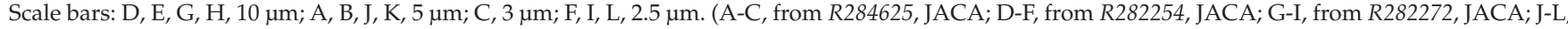
from $R 282230$, JACA). 


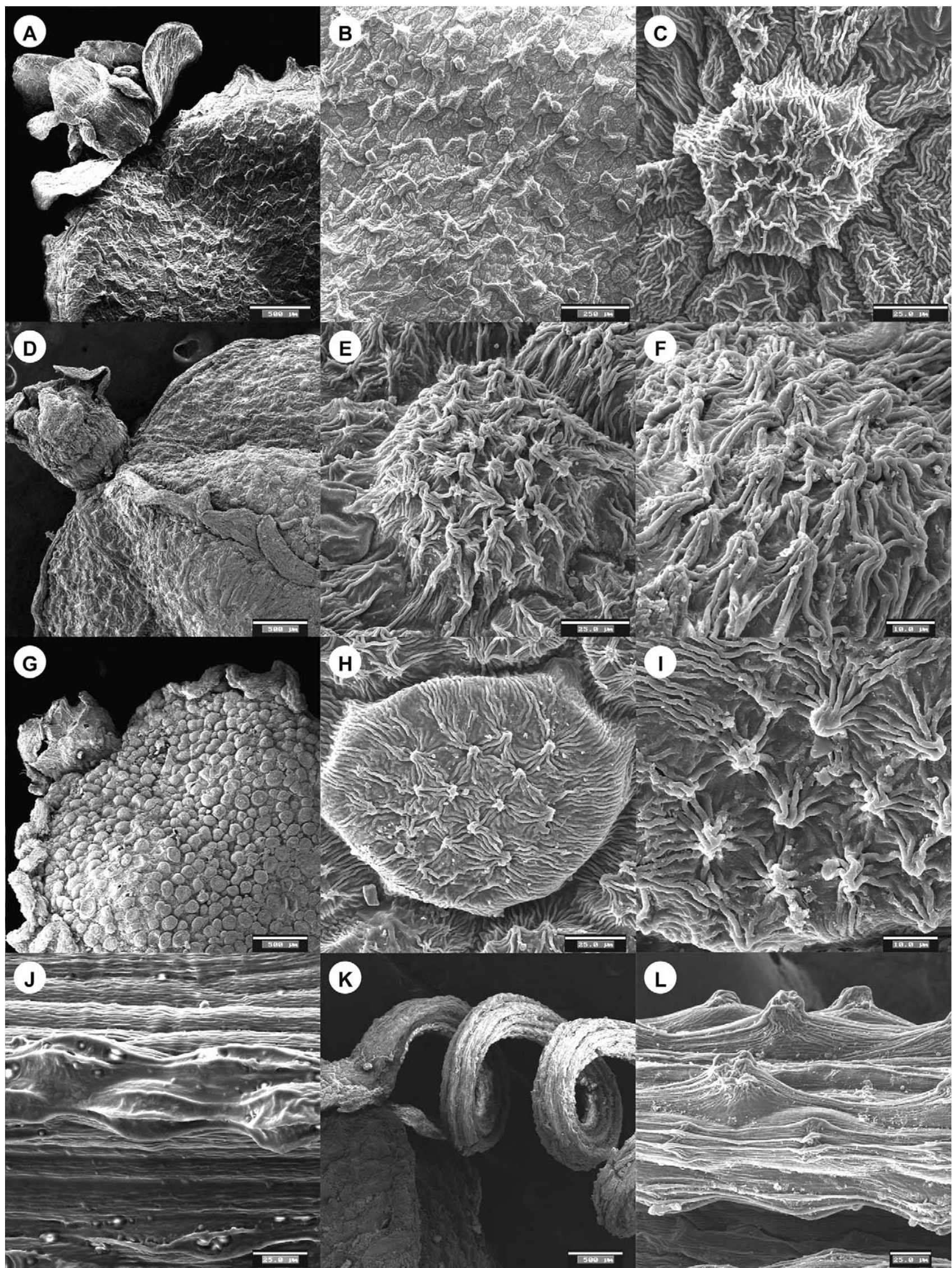

Fig. 5. Scanning electron microscopy photographs of capsules of the Epipetrum group of Dioscorea species. A-C, J. D. biloba s. 1. D-F, K. D. humilis. Figs. G-I, L. D. polyanthes. A, D, G. General views of capsule walls showing the senescent corolla. B. Capsule wall showing papillae and glands. C, E, H. Details of papillae. F, I. Details of periclinal cell wall sculpturing of papillae. J-L. Fruit peduncles and papillae from peduncles. Scale bars: A, D, G, K, $500 \mu \mathrm{m}$; B, $250 \mu \mathrm{m} ; \mathrm{C}, \mathrm{E}, \mathrm{H}, \mathrm{J}, \mathrm{L}, 25 \mu \mathrm{m} ; \mathrm{F}, \mathrm{I}, 10 \mu \mathrm{m}$. (A-C, J, from R282247, JACA; D-F, K, from R282278, JACA; G-I, L, from R282230, JACA). 


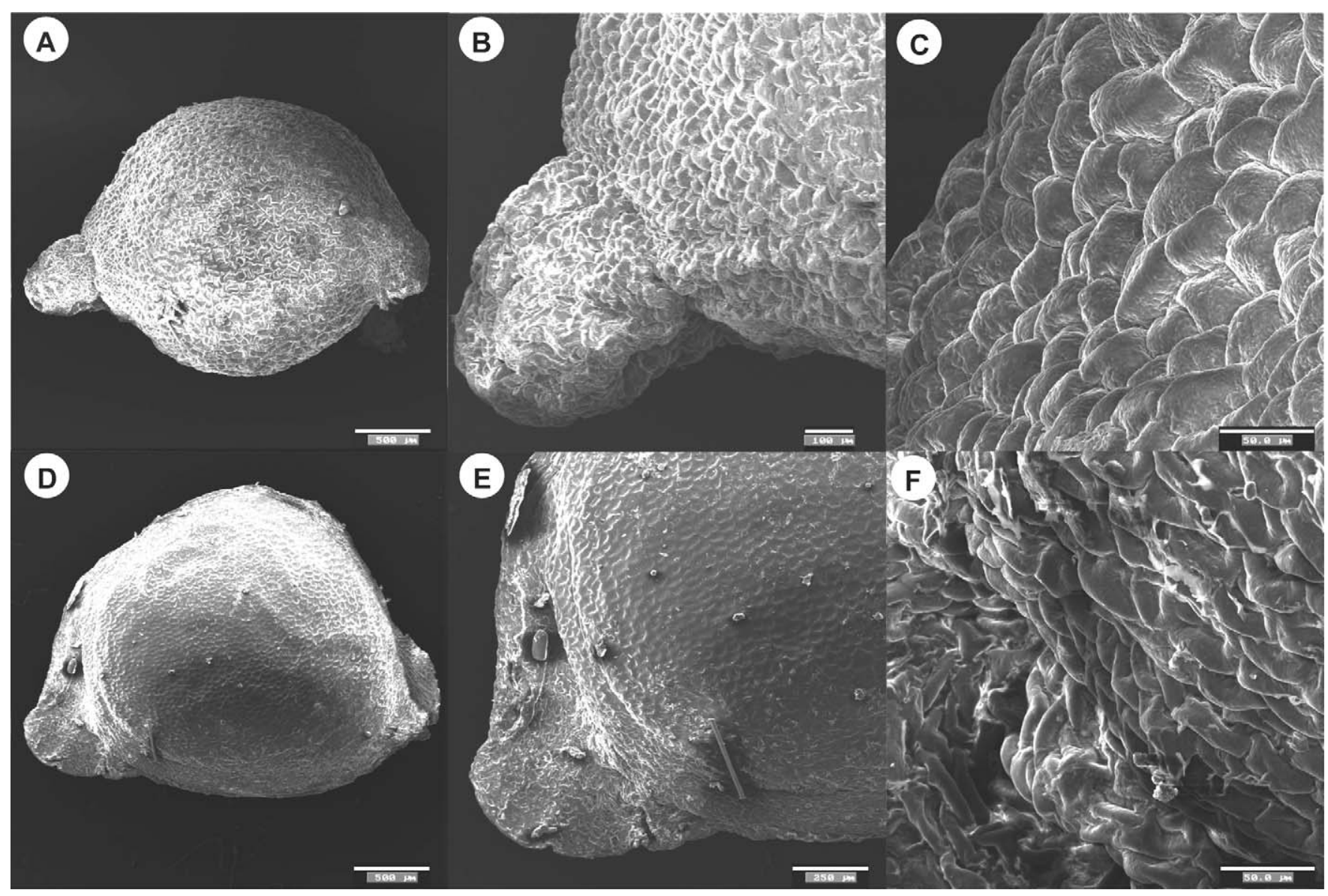

Fig. 6. Scanning electron microscopy photographs of seeds of the Epipetrum group of Dioscorea species. A-C. D. biloba s. 1. D-F. D. humilis s. 1. A, D General view. B, E. Detail of the caruncle. C, F. Detail of periclinal cell wall sculpturing from the caruncle. Scale bars: A, C, $500 \mu \mathrm{m}$; E, $250 \mu \mathrm{m} ; \mathrm{B}, 100 \mu \mathrm{m}$ C, F, $50 \mu \mathrm{m}$. (A-C, from R282234, JACA; D-F, from R282271, JACA).

stem and leaves alone. Forty-eight of 170 samples showed posterior probabilities lower than 1.0 in the cross validation test (results not shown). The inclusion of qualitative variables of leaves resulted in $100 \%$ correct classification of samples of both species, 22 of them with posterior probabilities lower than 1.0. The inclusion of fruit characters resulted in the correct classification of all samples with the maximum posterior probability. Wilks' Lambda values of the discriminant function for the three datasets were $0.162,0.136$, and 0.006 , respectively, indicating the better performance of the last combined matrix.

3. Northern D. BILOBa versus SOUTHERn D. BILOBA-The standard classification method of samples resulted in the correct classification of $96.3 \%$ and $98 \%$ of the northern and southern $D$. biloba samples, with respect to their predefined groups considering quantitative traits of stems and leaves alone. Forty-three out of 77 samples showed posterior probabilities lower than 1.0 in the cross validation test (results not shown). The inclusion of qualitative variables of leaves did not change the previous percentages of correct classification. The inclusion of fruit characters resulted in the correct classification of all samples with the maximum posterior probability. Wilks' Lambda values of the discriminant function for the three datasets were $0.242,0.240$, and 0.006 , respectively, indicating the higher discrimination power of the matrix containing all characters.
4. Dioscorea biloba versus D. humilis versus D. pOLYANTHES - The standard classification method of samples resulted in the correct classification of $100 \%, 83.9 \%$, and $80 \%$ of the $D$. biloba, D. humilis, and D. polyanthes samples to their predefined groups, respectively considering quantitative traits of stems and leaves alone. However, 120 out of 180 samples showed posterior probabilities lower than 1.0 in the cross validation test (results not shown). In the two-dimensional scatterplot, the D. biloba samples clustered in the right side of the first discriminant function, which accumulated $95.8 \%$ of the total variation, whereas samples of $D$. humilis and $D$. polyanthes clustered oppositely and were intermingled (Fig. 7A). The inclusion of qualitative variables of leaves resulted in the correct classification of all D. biloba and D. polyanthes samples, whereas $2.2 \%$ of the $D$. humilis samples were classified as $D$. polyanthes. Thirty-seven samples had a posterior probability value lower than 1.0. The 2-D scatterplot revealed an almost complete separation of the samples of $D$. biloba from the remaining samples along the first axis that accumulated $83.5 \%$ of the variation, whereas $D$. polyanthes and $D$. humilis separated along the second axis that accumulated $16.5 \%$ of the variation (Fig. 7B). However, one sample of D. humilis clustered close to $D$. polyanthes. The inclusion of fruit characters resulted in $100 \%$ correct classification of $D$. biloba and $D$. polyanthes samples and $96.6 \%$ of the D. humilis ones with all samples showing posterior probabilities of 1.0. The 2-D scatterplot 

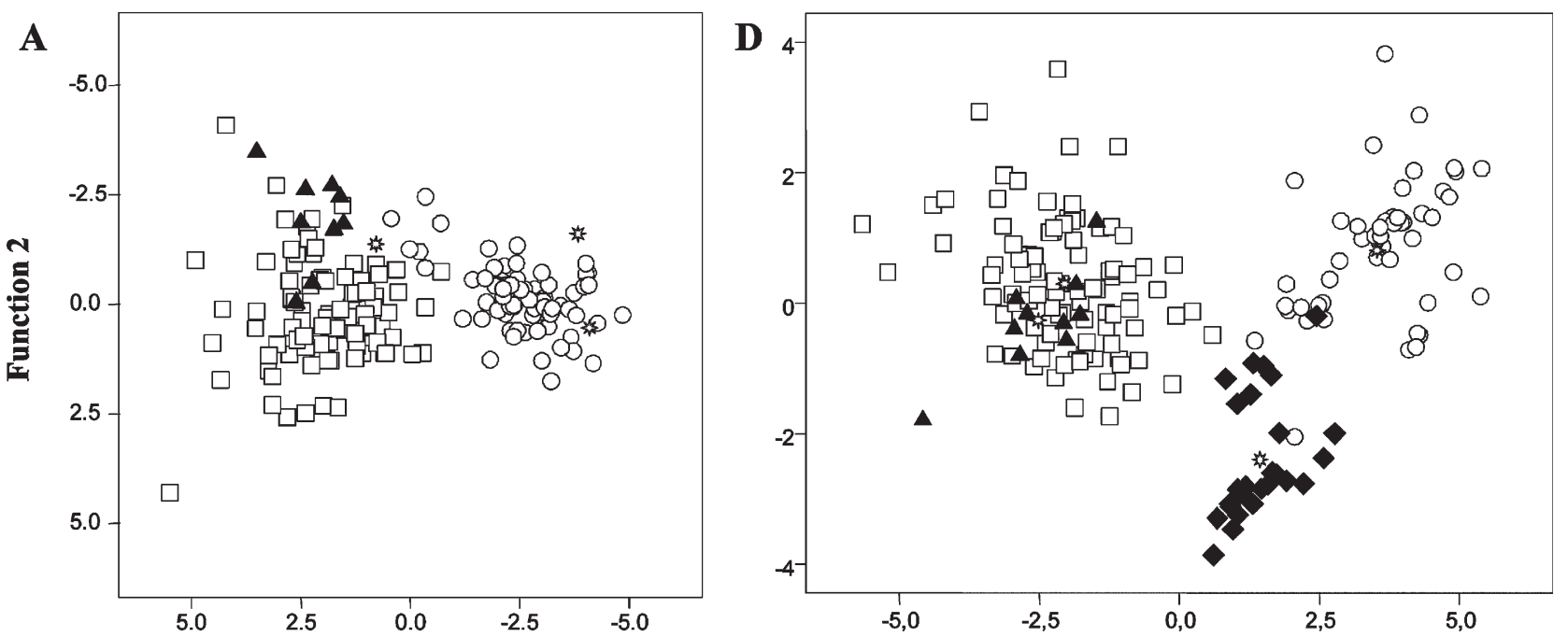

Function 1
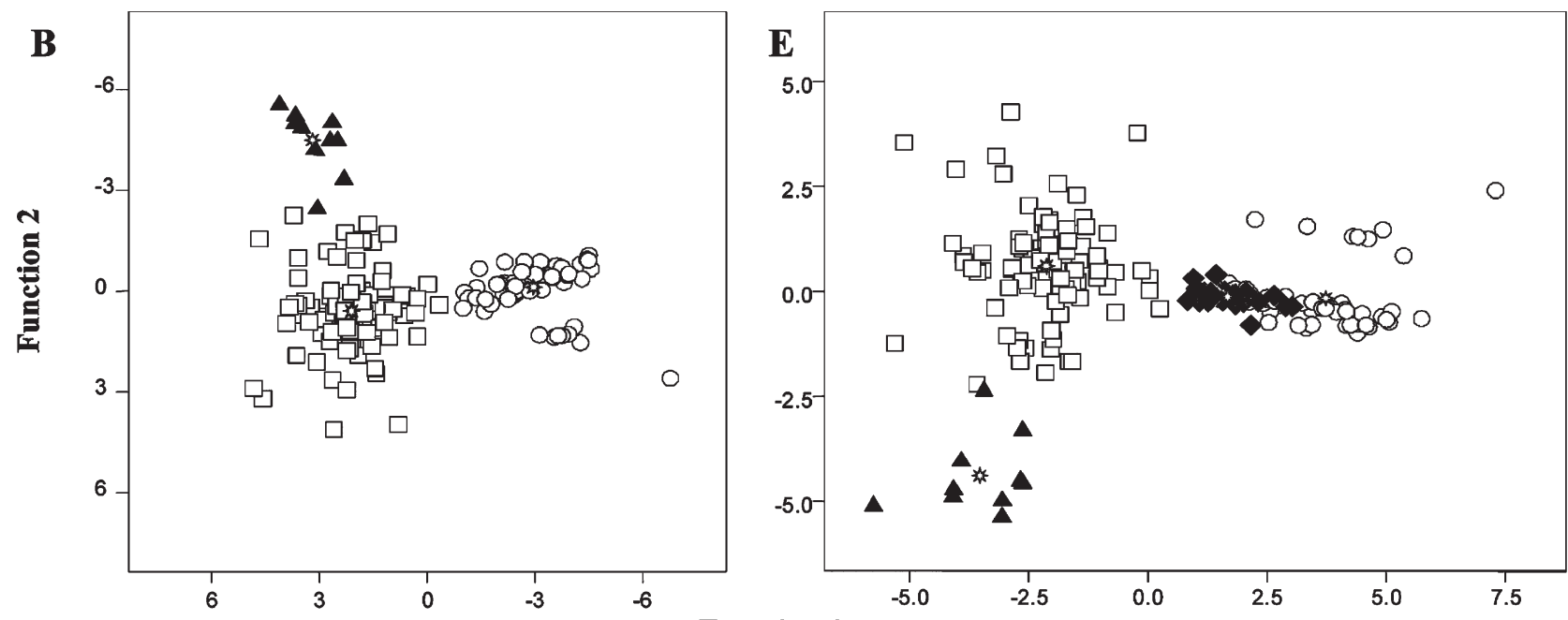

Function 1
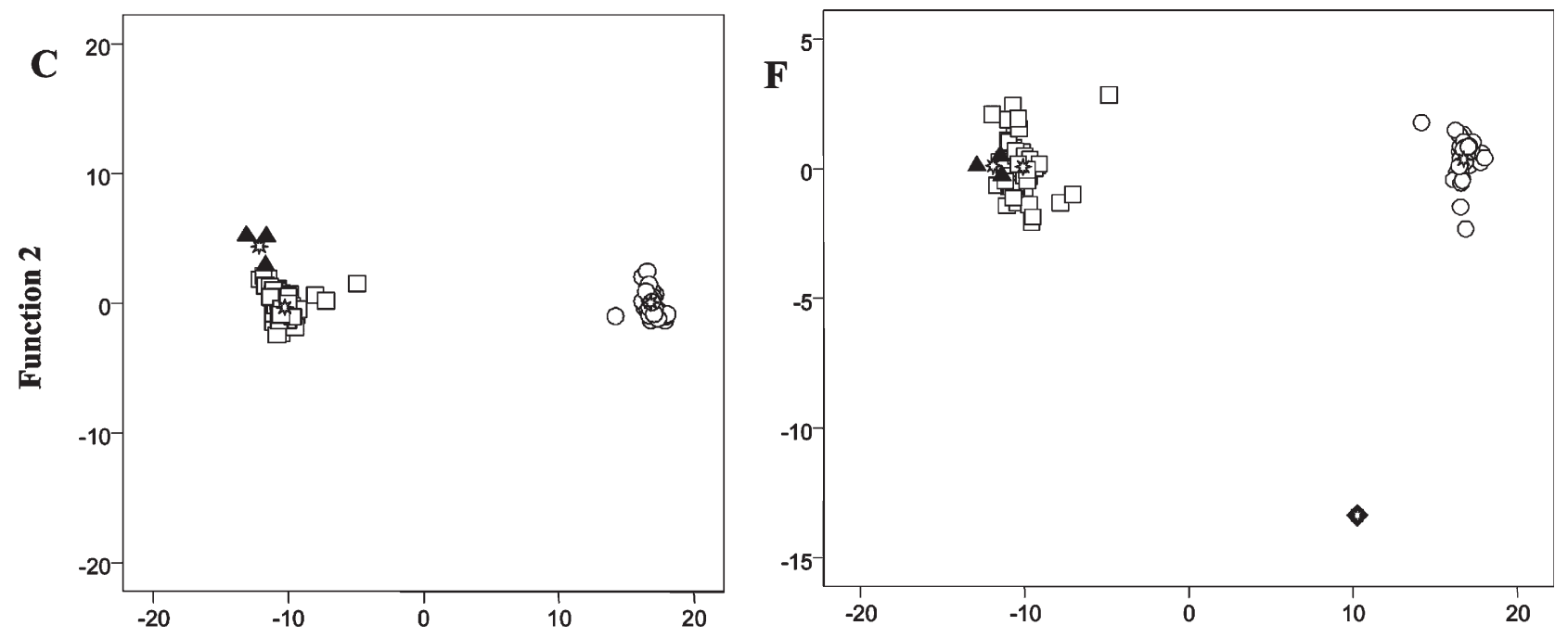

Function 1

FIG. 7. Two-dimensional scatterplots of classification Discriminant Analysis (DA) of the Epipetrum group of Dioscorea samples for taxonomic hypotheses 4 (A, B and C) and 7 (D, E and F) (see results). A, D. Quantitative dataset of stem and leaf characters. B, E. Combined quantitative and qualitative dataset of stem and leaf characters. C, F. Combined quantitative and qualitative dataset of leaf and fruit characters (see Table 2). The first Canonical discriminant function explained A, 95.8\%, B, 83.5\%, C, 99.5\%, D, 82.8\%, E, 95.7\% and F, 98.2\% of interspecies variation in each case. D. biloba s. 1 . (white circles in plots A, B and C), northern D. biloba (black diamonds in plots D, E and F), southern D. biloba (white circles in plots D, E and F), D. humilis (white squares) and D. polyanthes (black triangles); asterisks indicate group centroids. 
(Fig. 7C) revealed similar patterns to those obtained with the previous datasets (Figs. 7B, C) but a higher percentage of variation was accumulated along the first axis (99.5\%). The DAs confirmed that the separation of the morphologically similar $D$. humilis and D. polyanthes is supported solely by qualitative characters of leaves. Wilks' Lambda values of the first and second discriminant functions for the three datasets were $0.128-0.810,0.056-0.429$, and $0.003-0.590$, respectively. The lower Wilks' Lambda values obtained for the first discriminant function that separates $D$. biloba from the other two taxa of the Epipetrum group, indicates the greater morphological differentiation of this species, supporting its recognition at specific rank. By contrast, the higher Wilks' Lambda values obtained for the second discriminant function that separates $D$. humilis from $D$. polyanthes in all three datasets considered indicates the subtle morphological differentiation between these two taxa.

5. DiOSCOREA BILOBA VERSUS D. HUMILIS (AND D. POLYANTHES NOT ASSIGNED TO A PREDEFINED GROUP) - The standard classification method of samples resulted in the correct classification of $100 \%$ and $98.9 \%$ of samples of D. biloba and D. humilis to their predefined groups considering quantitative traits of stems and leaves alone. Only 10 of 170 samples showed posterior probabilities lower than 1.0 in the cross validation test (results not shown). The inclusion of qualitative variables of leaves and quantitative and qualitative variables of fruits resulted in the correct classification of $100 \%$ of the samples; however, the posterior probabilities of classification of samples were 1.0 only in the latter case. Wilks' Lambda values of the discriminant function for the three datasets were low $(0.162,0.136$, and 0.006$)$ in all cases. All samples of $D$. polyanthes grouped with $D$. humilis, regardless of the subset of morphological characters considered, and all classifications showed posterior probabilites of 1.0 in the three cases (results not shown), supporting the close morphological similarity of these two taxa.

6. Dioscorea biloba versus D. HUMilis (INCLUding D. POLYANTHES) - This analysis showed similar percentages of classification values to analysis 5 (above). The standard classification method of samples resulted in the correct classification of $100 \%$ and $91.8 \%$ of samples of D. biloba and D. humilis to their respective predefined groups considering quantitative traits of stem and leaves alone. Forty-five out of 170 samples showed posterior probabilities lower than 1.0 in the cross validation test (results not shown). The inclusion of qualitative variables of leaves and quantitative and qualitative variables of fruits resulted in the correct classification of $100 \%$ of the samples, but the posterior probabilities of classification of samples were 1.0 only in the latter case.Wilks' Lambda values of the discriminant function for the three datasets were, however, slightly lower $(0.158,0.132$, and 0.006 , respectively), indicating a less homogeneous structure of $D$. humilis if $D$. polyanthes is included within it.

7. Northern Dioscorea biloba Versus SOUthern D. BILOBA VERSUS D. HUMILIS VERSUS D. POLYANTHES - The standard classification method of samples resulted in the correct classification of $96.3 \%, 96 \%, 81.7 \%$, and $80 \%$ of the northern D. biloba, southern D. biloba, D. humilis, and D. polyanthes samples to their predefined groups considering quantitative traits of stems and leaves alone. However, 139 of 180 samples showed posterior probabilities lower than 1.0 in the cross validation test (results not shown). In the two-dimensional scatterplot, the $D$. biloba samples clustered in the right side of the first discriminant function that accumulated $82.8 \%$ of the total variation, whereas samples of D. humilis and $D$. polyanthes clustered oppositely and were intermingled (Fig. 7D). Northern and southern samples of D. biloba partially separated along the second discriminant function that accummulated $14.3 \%$ of the total variance. The inclusion of qualitative variables of leaves did not change the percentages of correct classification relative to northern and southern D. biloba samples, but improved the correct classification of all D. polyanthes samples, and $95.7 \%$ of the $D$. humilis ones. Seventyeight samples had a posterior probability value lower than 1.0. The 2-D scatterplot revealed a complete separation of the samples of $D$. biloba from the remaining samples along the first axis that accumulated $75.6 \%$ of the variation, whereas $D$. polyanthes and D. humilis partially separated along the second axis that accumulated $13.1 \%$ of the variation (Fig. 7E). One sample of $D$. humilis clustered close to D. polyanthes and northern and southern samples of D. biloba separated along the third discriminant function (not shown). The inclusion of fruit characters resulted in 100\% correct classification of northern and southern D. biloba and D. polyanthes samples and $96.6 \%$ of the D. humilis ones with all samples showing posterior probabilities of 1.0. The 2-D scatterplot (Fig. 7F) revealed a neat separation of $D$. biloba from $D$. humilis and $D$. polyanthes along the first axis that accumulated $98.2 \%$ of the variance. Northern and southern samples of $D$. biloba clearly separated along the second axis that accumulated $1.4 \%$ of the variance, whereas samples of $D$. humilis and D. polyanthes were intermingled. Wilks' Lambda values of the three discriminant functions for the three datasets were 0.052-0.386-0.816, 0.024-0.2050.471, and 0.001-0.226-0.593, respectively. The lower Wilks' Lambda values obtained for the first discriminant function that separates $D$. biloba s. 1. from $D$. humilis-D. polyanthes indicates the greater differentiation between the two morphological groups of readily recognized taxa of the Epipetrum group, suggesting the recognition of two species $D$. biloba and D. humilis. By contrast, the higher Wilks' Lambda values obtained for the second and third discriminant functions indicate the high similarity found within the two sample groups: $D$. humilis-D. polyanthes, which differ only in qualitative traits of the leaf (Fig. 4E), and northern and southern D. biloba populations, which separate in quantitative and qualitative traits of leaves and fruits (Fig. 4D, F). These results suggest the recognition of two subspecies within each $D$. biloba and D. humilis.

\section{DiscUSSION}

The macromorphological analysis has enabled us to characterize and differentiate the Epipetrum group taxa at the specific and subspecific levels and to compare them to other winglessseeded taxa of Dioscoreaceae. The Epipetrum group shows an exclusive combination of morphological traits that differentiate it from all other wingless-seeded members of the family (Figs. 8-11). It differs from the Tamus group of Dioscorea in the absence of a climbing habit, the shorter stems and smaller leaves, and the presence of capsules (instead of fleshy berries); from the Borderea group in the globose tuber totally covered by roots, in contrast to the elongate xylopodium (Segarra and Catalán 2005); and from the Nanarepenta group in leaf morphology and male and female inflorescence types (shorly racemose to cymose male inflorescences producing pedicellate six-staminate flowers in the Epipetrum group versus racemose male inflorescences with sessile three-staminate flowers 


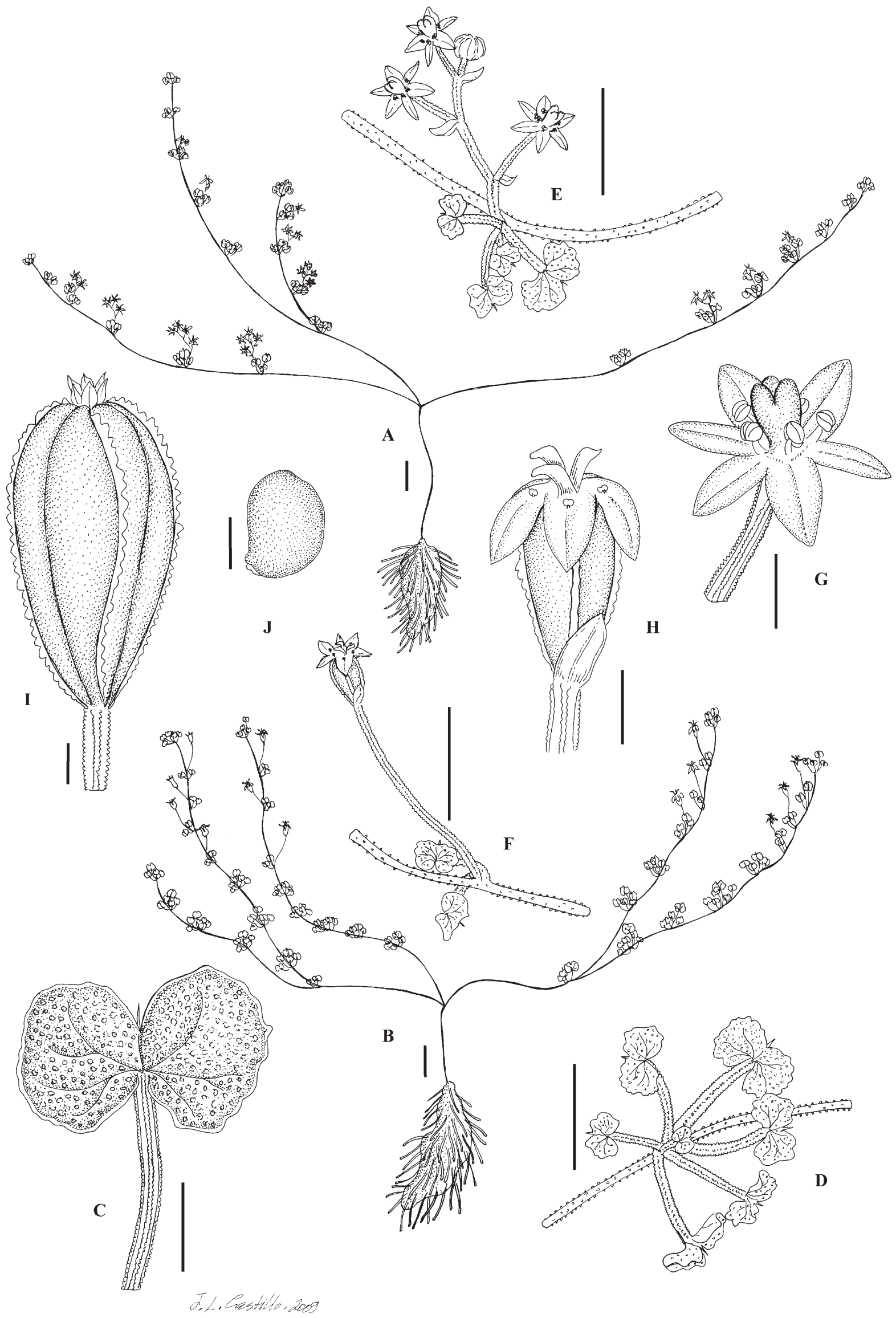

Fig. 8. Dioscorea biloba subsp. biloba. A. Habit of male plant. B. Habit of female plant. C. Adaxial side of leaf. D. Detail of leafy stem node. E. Detail of a male flowering node. F. Detail of a female flowering node. G. Male flower. H. Female flower. I. Fruit. J. Seed. Scale bars: A, B, $1 \mathrm{~cm}$. D, E, F, 5 mm. C, 2 mm. G, H, I, J, 1 mm. (A, C-E, G, from R284623, JACA; B, F, H, from R284624, JACA, I, J, from Werdermann 866, K). 
in the Nanarepenta group, and long female inflorescences usually producing a single flower in the Epipetrum group versus shorter inflorescences producing up to five flowers in the Nanarepenta group; Téllez-Valdés and Dávila-Aranda 1998). The Epipetrum group also differs from all these groups in having prominent pistillodes in male flowers (Figs. 8-11) and a base chromosome number of $x=7$, with mostly diploid individuals $(2 n=14)$ (Viruel et al. 2008), in contrast to the base chromosome numbers of $x=6$ with tetraploids $(2 n=24)$ in the Borderea group (Heslot 1953; Catalán et al. 2006) and octoploids $(2 n=48)$ in the Tamus group (Meurman 1925), and of $x=9,10$, or 20 with diploid to 14-ploids in Dioscorea s. s. (Smith 1937; Scarcelli et al. 2005; Bousalem et al. 2006; Viruel et al. 2008). The character of prominent pistillodes is restricted in Dioscorea s. s., reported only for Dioscorea Sect. Macrogynodium Uline (Knuth, 1924), which includes D. stegelmanniana Knuth, with pistillodes that are three times shorter than in the Epipetrum group, the edible yam D. trifida L. with $x=20$ (Bousalem et al. 2006), and D. remotiflora Kunth., with rugulate pollen ornamentation (Schols et al. 2003).

The pollen of the Epipetrum group is shown here to be bisulcate in all taxa (Fig. 4), contrasting with a previous report of monosulcate pollen in D. biloba (Caddick et al. 1998). This difference might have resulted from difficulties in establishing the number of pollen apertures in SEM analysis or from the infraspecific variability of the number of pollen aperture number, as reported for other Dioscorea taxa (Caddick et al. 1998; Schols et al. 2003, 2005). Our pollen analysis has also shown the presence of a perforate-reticulate exine (Fig. 4), which has also been reported in many species of Dioscorea s. s. (Caddick et al. 1998; Schols et al. 2003, 2005), the Nanarepenta group (Téllez-Valdés and Dávila-Aranda 1998; Schols et al. 2005), and the Tamus group (Caddick et al. 1998; Schols et al. 2001, 2003), but is totally different from the gemmate exine of the Borderea group (Caddick et al. 1998; Schols et al. 2003, 2005).

All taxa in the Epipetrum group exhibit the same kind of glandular hairs, a trichome morphology that has also been reported in Dioscorea (Tamus) communis (L.) Caddick \& Wilkin (Orr 1926; Bruni et al. 1987) although in this species the glandular hairs are ten times longer than that those of the Epipetrum group.

Recent phylogenetic studies, with a broader perspective of the Dioscoreaceae and based on morphological and molecular data, have placed the wingless-seeded groups (the Borderea, Epipetrum, Nanarepenta, Rajania, and Tamus groups) as nested in Dioscorea (Caddick et al. 2002a) and have subsequently taxonomically subsumed them within it (Caddick et al. 2002b). However, the Epipetrum group was represented only in the tree based on morphology, and molecular data had not been available (Caddick et al. 2002a, b). Our preliminary analysis indicates that the Epipetrum group emerges as a clade closely related to some South American Dioscorea s. s. and the Nanarepenta group, whereas the apparent dwarf habit and unwinged seed character shared with other small natural groups of wingless Dioscoreaceae seem to be the consequence of morphological convergence in separate evolutionary lineages of yams (Viruel et al. unpublished data).

Our study is the first to explore exhaustively the morphoanatomical variation across the three taxa of the Epipetrum group. This systematic revision has allowed us to delimit taxonomically the two most distinct taxa, D. humilis and D. biloba, which have been recognized as separate species. Our survey has also highlighted the minor morpho-anatomical differences between $D$. polyanthes and $D$. humilis, and the relatively higher variation between northern and southern populations of $D$. biloba, which favors a subspecific treatment in both cases.

Our review presents the first micromorphological study of the Epipetrum group of Dioscorea, which has provided a set of additional characters related to the sculpturing of epidermal cells (Figs. 2, 3) that further supports the taxonomic limits of the four entities. Southern D. biloba is unique in having rounded bulging papillae with striate periclinal walls in the petioles (Figs. 2F, 3M) and peduncles (Fig. 5J), contrasting with the acute ones found in northern $D$. biloba (Fig. 2C) and in both D. humilis and D. polyanthes (Figs. 3O, 5L). Stellate periclinal walls of papillae from the adaxial side of the leaves also differentiate southern D. biloba (Figs. 3D, F) from northern $D$. biloba, D. humilis, and D. polyanthes, which have stellate-reticulate ornamentation (Figs. 3A, C, G, I, J, L). These two latter taxa differ slightly in the ornamentation of the papillae of the abaxial sides of the leaf, which are stellate-reticulate in D. humilis (Fig. $3 \mathrm{H}$ ) and striate in D. polyanthes (Fig. 3K). Fruit (Fig. 5) and seed (Fig. 6) micromorphological traits do not provide a clear differentiation of any of the four taxa.

The statistical analyses have provided the means to select the quantitative and qualitative traits that best discriminate the four taxa of the Epipetrum group (Fig. 7; Tables 1-2). The classification DA approach has been widely employed in systematic studies of a variety of angiosperm genera (Robart 2005) and to discern among closely related taxa and potential hybrids, including complex aggregates with few morphological differences (Christensen 1984; Oja and Paal 2006; Koutecky 2007; McCauley and Ballard 2007). Our analyses demonstrate that the distinctness of $D$. biloba from the remaining taxa of the Epipetrum group is clear and supported by many quantitative and qualitative traits (Figs. 8-9) of different vegetative and reproductive plant organs, confirming its recognition at specific rank. Our analyses also revealed remarkable differences both in macro- and micromorphological traits between northern and southern populations of D. biloba. Northern D. biloba are distinguishable by the overall smaller size of vegetative organs, the densely papillose leaves (Fig. 8), and the reddish abaxial sides of the leaf (a character that is maintained when plants are cultivated in common garden conditions), compared to the larger size of vegetative organs, the slightly papillose leaves (Fig. 9), and the green abaxial sides of the leaf observed in southern D. biloba. Analysis of micromorphological characters of papillae also revealed the stellate-reticulate ornamentation in northern D. biloba (Fig. 3A-C), which differs from the stellate ornamentation in southern $D$. biloba (Fig. 3D-F). Therefore, a new subspecies is described below for the southern populations of D. biloba.

By contrast, the recognition of $D$. humilis and $D$. polyanthes as separate species is less clear. Discriminant analyses confirms the paucity of differences observed between these two taxa based on both macro- and micromorphological characters, suggesting that a reliable identification of individuals is only possible with qualitative traits of leaves (Figs. 2, 10C, 11C-D). These small morphological differences between $D$. humilis and D. polyanthes do not justify recognition at the rank of species, and these taxa are recognized as two subspecies of the same species in the treatment below.

\section{TAxonomic TReATMent}

General Characters of the Epipetrum group of DioscoreaGeophytes with herbaceous annual aerial shoots. Tubers to 


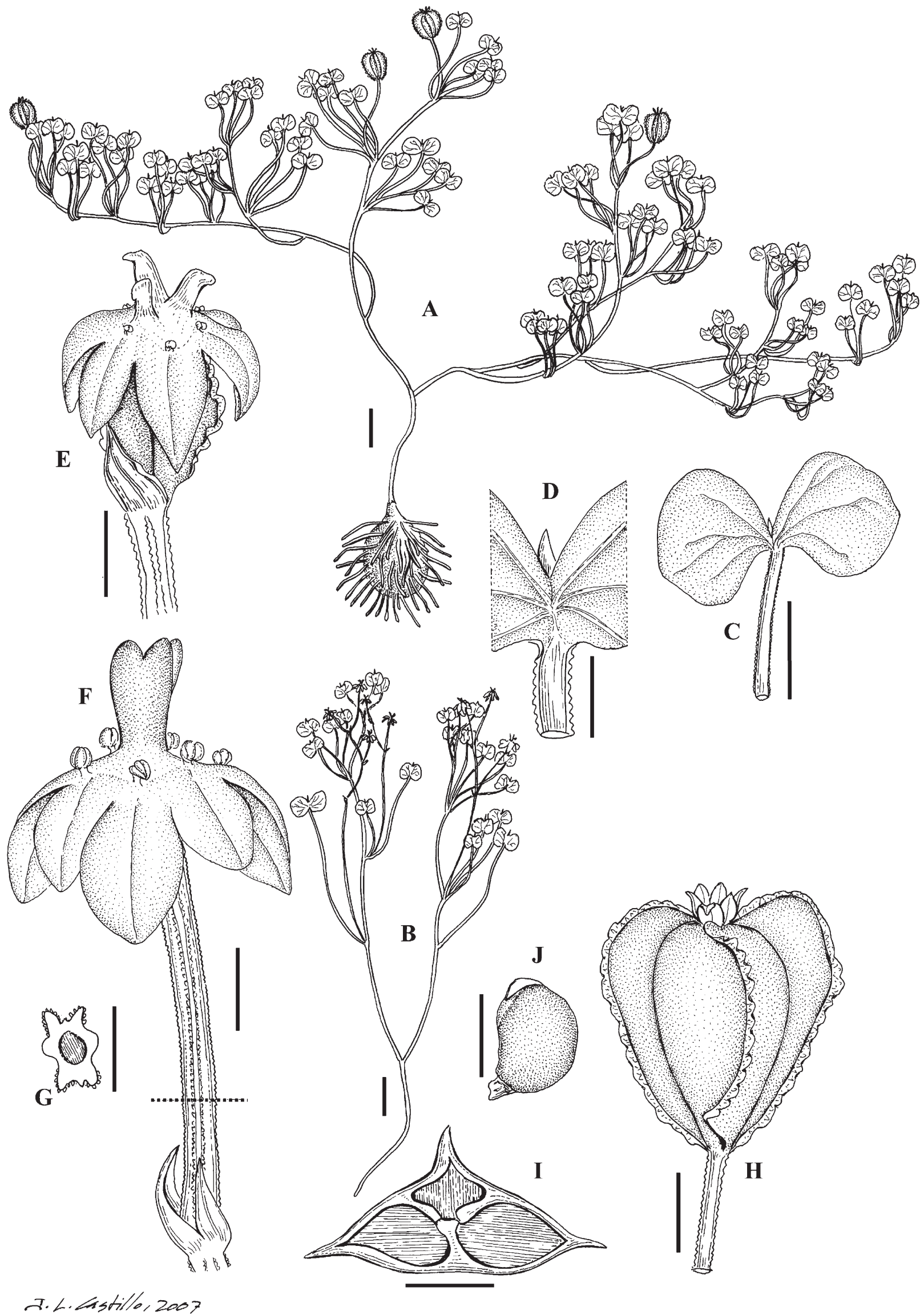

Fig. 9. Dioscorea biloba subsp. coquimbana. A. Habit of female plant. B. Partial habit of male plant. C. Adaxial side of leaf. D. Detail of leaf apex. E. Female flower. F. Male flower. G. Cross section of pedicel. H. Fruit. I. Cross section of fruit. J. Seed. Scale bars: A, B, F, $1 \mathrm{~cm}$. C, 5 mm. H, I, J, 2 mm. E, D, $1 \mathrm{~mm}$. G, 0.5 mm. (A, C-E, from R282236, JACA; B, F, G, from R282233, JACA; H-J, from R282234, JACA). 


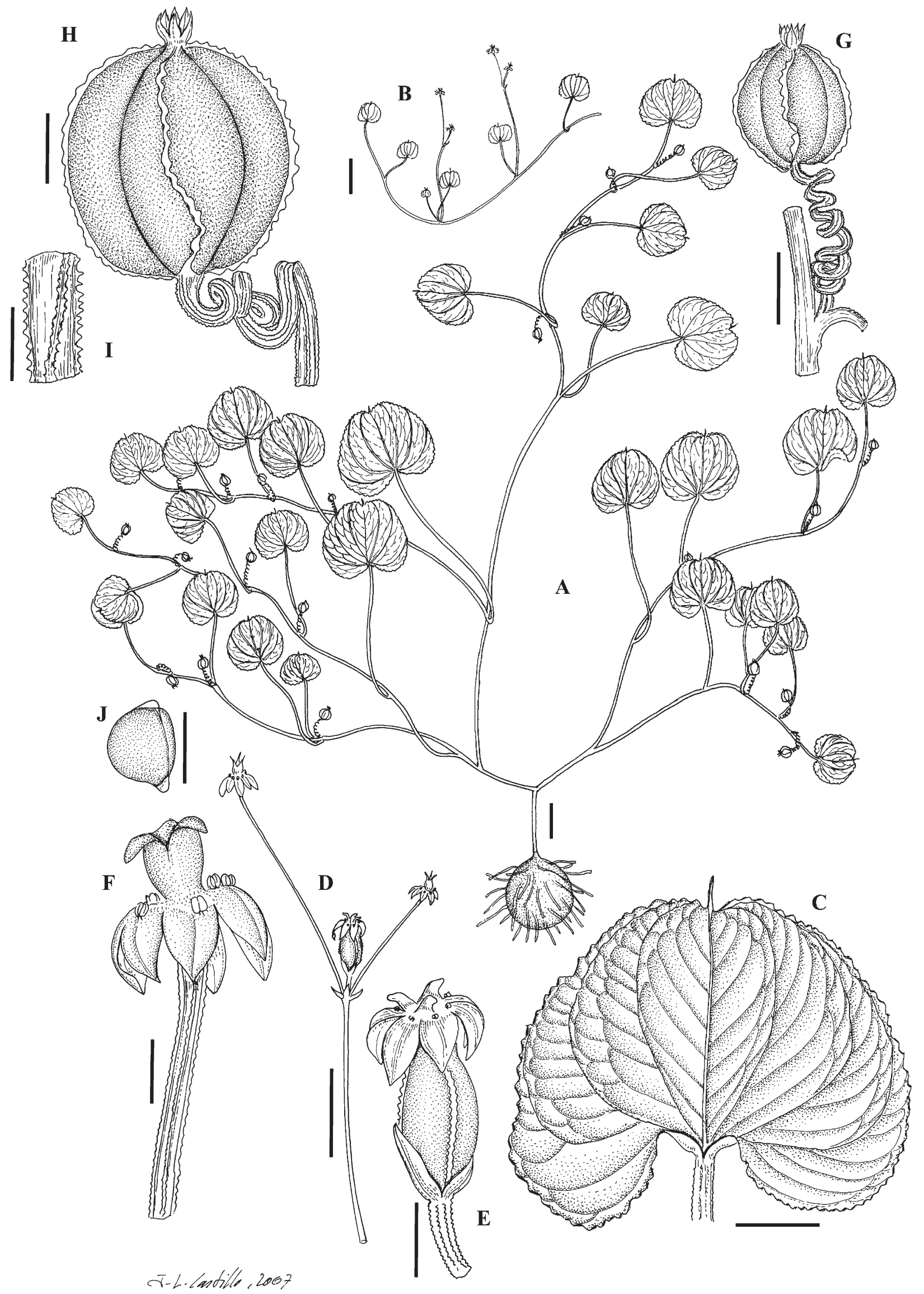

FIG. 10. Dioscorea humilis subsp. humilis. A. Habit of female plant. B. Partial habit of male plant. C. Adaxial side of leaf. D. Male inflorescence with a basal female flower. E. Female flower. F. Male flower. G. Immature fruit. H. Mature fruit. I. Papillae from peduncle. J. Seed. Scale bars: A, B, 1 cm. C, D, $5 \mathrm{~mm}$. G, H, J, 2 mm. E, F, 1 mm. I, 0.5 mm. (A, C, G-J, from R282243, JACA; E, from R282239, JACA; B, F, D, from R282237, JACA). 


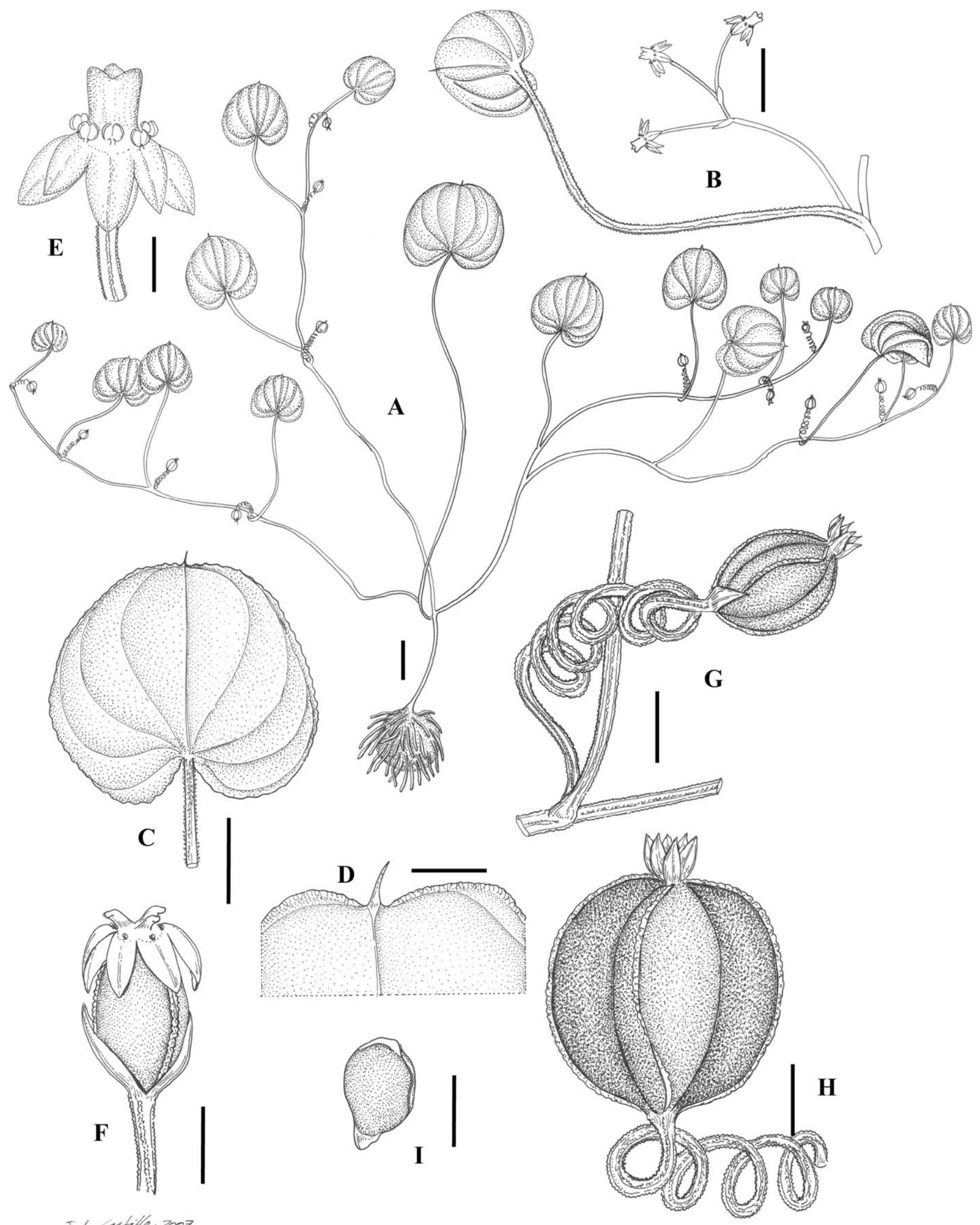

Fig. 11. Dioscorea humilis subsp. polyanthes. A. Habit of female plant. B. Partial habit of male plant. C. Adaxial side of leaf. D. Detail of leaf apex. E. Male flower. F. Female flower. G. Immature fruit. H. Mature fruit. I. Seed. Scale bars: A, $1 \mathrm{~cm}$. B, C, 5 mm. D, G, H, I, 2 mm.. E, F, 1 mm. (A-G, from R282231, JACA; H-I, from R282230, JACA). 
$3 \times 3 \mathrm{~cm}$, irregularly shaped to globose, covered by roots. Shoots single, trailing, branching at $0.4-15 \mathrm{~cm}$ from the tuber, herbaceous. Leaves petiolate; petioles up to $13 \mathrm{~cm}$ long, papillose and glandulose (glands visible only under microscope). Leaves alternate, opposite or whorled, obovate or bilobate, papillose, and sparsely covered with glandular hairs on both sides; leaf apex emarginate, mucronate; leaf margin entire or slightly papillose-crenulate. Dioecious or rarely monoecious. Flowers unisexual by reduction. Flowers bracteolate, with two bracteoles up to $1.7 \mathrm{~mm}$ long; trimerous; perianth 2-whorled, isomerous, greenish, composed of six tepals up to $1.8 \times 1 \mathrm{~mm}$, patent, horizontal, or squarrose. Male inflorescences manyflowered and in axillary cymes, persistent or deciduous. Male flowers pedicellate, hypogynous; androecium with six stamens up to $0.4 \mathrm{~mm}$ long; gynoecium reduced to a dark-purple prominent pistillode comprising 3 stylodes to $4.4 \mathrm{~mm}$ long. Pollen bisulcate with perforate-finely reticulate exine. Female inflorescences axillary, with one (or two) flowers. Female flowers epigynous, pedicellate; pedicels filiform, flexuose; androecium reduced to six staminodes; gynoecium three-carpellate, syncarpous, tristylar, styles free. Ovary to $3 \mathrm{~mm}$ long, threelocular. Ovules two per locule. Fruit a capsule to $7.8 \times 7.5 \mathrm{~mm}$, pedunculate; peduncle straight, filiform or spirally curled, papillose; globose or ovoid, crowned by persistent perianth, three-angled in transection, papillose and sparsely covered with glandular hairs; loculicidal; seeds usually six, two per locule, reddish-brown, ovoid or ellipsoidal and globose, wingless, up to $2.8 \times 2 \mathrm{~mm}$, carunculate. Chromosome number, $2 n=14$, rarely $2 n=28$ in D. humilis subsp. humilis (Viruel et al. 2008).

As Philippi (1862) noted, Bertero misinterpreted the flower of $D$. humilis as being hermaphroditic. It was Philippi who pointed out the existence of prominent pistillodes in the male flowers, the most notable diagnostic feature of the genus together with its unique base chromosome number of $x=7$ (Viruel et al. 2008). Although there is no explicit reference to this trait in the original description of $D$. humilis, this species was described as having separate-sex inflorescences but not being strictly dioecious (Colla 1836). The Epipetrum group is mostly dioecious, although monoecious individuals having both male and female unisexual flowers are present in some northern populations of D. humilis and in some southern populations of $D$. biloba, mixed with typically dioecious ones. Although those individuals are not rare in the northern populations of $D$. humilis, they indicate that the mechanism of sex determination in this group of Dioscorea still needs to be investigated.

1. Leaves wider than longer, distinctly bilobed. Fruiting peduncles linear, filiform. Capsule obovoid (1. D. biloba) ................... 2 2. Petioles short $(5.77 \mathrm{~mm})$, leaves small (means $=2.6 \times 4.3 \mathrm{~mm})$, densely papillose, abaxial side reddish ........... 1.1. D. biloba subsp. biloba

2. Petioles long $(17.56 \mathrm{~mm}$ ), leaves larger (means $=4.15 \times 6.7 \mathrm{~mm}$ ), slightly papillose, abaxial side green ....... $1.2 \mathrm{D}$. biloba subsp. coquimbana

1. Leaves as wide as long, obovate, sometimes with emarginate apex but not distinctly bilobed. Fruiting peduncles

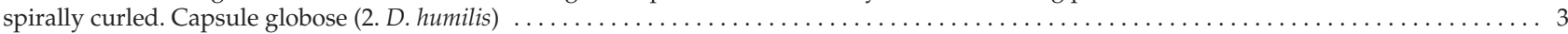
3. Leaves not fleshy, reticulate, with marked secondary venation and grooved interstices $\ldots \ldots \ldots \ldots \ldots$. . . . . . . 2.1. D. humilis subsp. humilis 3. Leaves somewhat fleshy, without marked secondary venation and interstices not grooved ................2.2 D. humilis subsp. polyanthes

1. Dioscorea Biloba (Phil.) Caddick \& Wilkin, Taxon 51: 112. 2002.Epipetrum bilobum Phil., Anales del Museo Nacional de Santiago de Chile, p. 11, Table 3. Figure 1. 1892.-TYPE: CHILE. "Habitat in deserto Atacama loco dicto Breas, Nov 1888, Alamiro Larrañaga", 47242 (holotype: SGO! sub Thaumasta biloba Phil. nomen in schedis).

Tubers irregularly shaped to globose, $8 \times 3 \mathrm{~cm}$, covered by roots. Annual aerial shoots herbaceous, single, trailing and branching at $1-15 \mathrm{~cm}$ from the tuber, to $33.5 \mathrm{~cm}$ long. Leaves whorled (up to 14 per node), petiolate and bilobed; petioles (1.2-) 14.05 (-82) $\mathrm{mm}$ long, papillose, the papillae bulging rounded or acute with striate periclinal walls; lamina (1.1-) $3.7(-15.8) \times(1.2-) 5.54(-17.5) \mathrm{mm}$, wider than longer, strongly bilobate, with entire margin, and mucronate apex, membranous, papillose, and sparsely covered with glandular hairs on both sides; papillae colorless or reddish with stellate or stellate-reticulate periclinal walls. Inflorescences axillary. Male inflorescences shortly racemose to cymose, persistent. Male flowers pedicellate; pedicel (0.75-) 6.8 (-16) $\mathrm{mm}$ long. Female inflorescences axillary, female flowers solitary, rarely geminate to three per inflorescence, pedicellate; pedicel (1.2-) 12.41 (-35) mm long. Capsule obovoid, (3-) 5.65 (-9) × (3-) 5.32 $(-7.5) \mathrm{mm}$, papillose and glandulose, pedunculate, the papillae with striate-reticulate periclinal walls; peduncle filiform straight or flexuose and papillose; the papillae acute with striate periclinal walls. Seeds ovoid and globose, (1-) $1.76(-2.3)$ $\times(0.6-) 1.44(-2) \mathrm{mm}$, reddish, wingless, with a small caruncle (0.1) 0.31 (0.7) mm long.

Notes-Despite the application of the neuter epithet "bilobum" to the feminine generic name Dioscorea by Caddick et al. (2002b), Article 32.7 of the International Code of Botanical
Nomenclature (Vienna Code) provides for an orthographic correction of such an error (without amendment of the authority or publication date) and thus the name appeared correctly (as Dioscorea biloba) in Govaerts et al. (2007).

Dioscorea biloba has a remarkably disjunct distribution (Fig. 1). The northern populations of Antofagasta, where the species was first discovered, are $600 \mathrm{~km}$ from the southern ones at the Coquimbo region and from the main center of distribution of the other taxa of the Epipetrum group. Given the apparent short distances typical of seed dispersal for this group, the disjunct distribution pattern could indicate the fragmentation of an earlier and larger distribution area. Our expeditions allowed us to collect abundant materials from both areas. Our comparative analyses revealed significant morphological differences between the two distribution areas and consequently, two subspecies are recognized within this taxon:

\subsection{Dioscorea biloba (Phil.) Caddick \& Wilkin subsp. вiloba.}

Tubers irregularly shaped, $8 \times 3 \mathrm{~cm}$. Annual aerial shoots up to $23 \mathrm{~cm}$ long and up to $0.2 \mathrm{~mm}$ wide. Leaves whorled (3-7 per node); petioles (1.2-) 5.77 (-26) mm long, papillose, the papillae acute with striate periclinal walls; lamina (1.1-) 2.6 $(-8) \times(1.7-) 4.3(-11.8) \mathrm{mm}$, profusely papillose; adaxial side green, abaxial side reddish; papillae of adaxial side colorless with stellate-reticulate periclinal walls and those of abaxial side reddish with stellate-reticulate periclinal walls. Pedicels of male flowers (0.75-) $2.67(-4.1) \mathrm{mm}$ long. Female flowers solitary, rarely three per inflorescence; pedicel of female flowers (2.5-) $7.38(-12) \mathrm{mm}$ long. Capsule obovoid, (7-) $8.3(-9) \times$ (4-) $4.16(-4.5) \mathrm{mm}$. Seeds ovoid and globose, $2 \times 1 \mathrm{~mm}$, reddish brown. Figure 8. 
Phenology-Flowering from August to October.

Habitat and Distribution-Dry limestone rocks and crevices in open habitats near Taltal in Antofagasta (II) region (Figs. 1, 12A, C).

Notes-This taxon is currently known from three geographically close populations located in a single mountain (Cerro Perales) covering an area of no more than $1 \mathrm{~km}^{2}$. As far as we know, there are a total of about 300 individuals, of which only $10 \%$ are reproductive. The distribution has not increased since the time of the original description more than a century ago in 1892. It is restricted to an arid habitat with frequent fogs, where individual recruitment is extremely difficult and there is abundant mining activity in the surrounding areas. Given all this, this taxon should be considered Critically Endangered CR B1a, $\mathrm{b}_{(\mathrm{i}+\mathrm{i}+\mathrm{i} \text { ) }}, \mathrm{B} 2 \mathrm{a}, \mathrm{b}_{(\mathrm{i}+\mathrm{ii}+\mathrm{iv})^{\prime}}, \mathrm{C} 2 \mathrm{a}_{(\mathrm{i})}$ (IUCN 2008), and habitat protection is strongly encouraged.

Representative Specimens Examined-CHILE. Antofagasta region (region II): Dept. Taltal, Taltal, ca. 400 m, Oct 1925, Werdermann 866 (B, K). Dpto. Taltal, ca. $6 \mathrm{~km}$ east of Taltal; crevices under rocks, moist and sheltered. Annual herbs to $5 \mathrm{~cm}$; fl. brownish green; lvs. reddish on reverse. Oct. 14, 1938. Worth and Norrison 16116 (K). Taltal, cerro Perales, pista que sube al repetidor, $25^{\circ} 25.631^{\prime} \mathrm{S} 70^{\circ} 25.515^{\prime} \mathrm{W}$, ladera orient. S con rocas aparentemente calizas, relativa humedad, 24 Aug 2008, Villar and Viruel R284620 (JACA). Cerro Perales, pista que sube al repetidor, $25^{\circ} 25.676^{\prime} \mathrm{S}$ $70^{\circ} 25.503^{\prime} \mathrm{W}$, ladera orient. S con rocas aparentemente calizas, relativa humedad, 25 Aug 2008, Villar and Viruel R284621 (JACA). Cerro Perales, pista que sube al repetidor, $25^{\circ} 25.623^{\prime} \mathrm{S} 70^{\circ} 25.616^{\prime} \mathrm{W}$, ladera orient. S con rocas aparentemente calizas, relativa humedad, 25 Aug 2008, Villar and Viruel R284622, R284623, R284624, R284625 (JACA). Cerro Perales, pista que sube al repetidor, $25^{\circ} 25.691^{\prime} \mathrm{S} 70^{\circ} 25.672^{\prime} \mathrm{W}$, Ladera orient. $\mathrm{S}$ con rocas aparentementes calizas, relativa humedad, 26 Aug 2008, Villar \& Viruel R284626, R284627, R284628 (JACA).

1.2. Dioscorea biloba (Phil.) Caddick \& Wilkin subsp. coquimbana Viruel, Segarra-Moragues \& Villar, subsp. nov.TYPE: Chile: Coquimbo Region: Carretera de Parral de Quiles a San Pedro de Quiles, 30 57'630' S, 71 $28^{\prime} 417^{\prime \prime} \mathrm{W}$, grietas de rocas calizas junto a la carretera, 23 Aug 2006, Segarra-Moragues and Pérez-Collazos R282236 (holotype: JACA!) R282252, R282253 (paratypes: JACA!).

Differt a D. biloba (Phil.) Caddick \& Wilkin subsp. biloba petiolis quidem longioribus (17.56 nec $5.77 \mathrm{~mm}$ longis), foliis item longioribus (4.15 nec $2.6 \mathrm{~mm}$ longis) atque latioribus (6.7 nec $4.3 \mathrm{~mm}$ latis), lamina foliari abaxialiter viridi, nec rubella, et adaxialiter sparse, nec dense, papillosa.

Tubers globose, $2.8 \times 3 \mathrm{~cm}$. Annual aerial shoots up to $33.5 \mathrm{~cm}$ long and up to $0.8 \mathrm{~mm}$ wide. Leaves whorled (3-14 per node); petioles (3-) 17.56 (-82) mm long, papillose, the papillae rounded with striate periclinal walls; lamina (1.1-) 4.15 $(-15.8) \times(1.5-) 6.7(-17.5) \mathrm{mm}$, papillose; adaxial and abaxial sides green; papillae of adaxial and abaxial sides colorless with stellate periclinal walls. Pedicels of male flowers (4-) 8.9 (16) $\mathrm{mm}$ long. Female flowers solitary, rarely geminate; pedicel of female flowers (1.2-) 14.25 (-35) mm long. Capsule obovoid, (3-) $5.55(-9) \times(3-) 5.36(-9) \mathrm{mm}$. Seeds ovoid and globose, (1-) $1.75(-2.3) \times(0.6-) 1.46(-2) \mathrm{mm}$, reddish. Figure 9 .

Etymology-The subspecific epithet refers to the Chilean region of Coquimbo, where this taxon is distributed.

Phenology-Flowering from July to August.

Habitat and Distribution-Dry limestone rocks and crevices in open habitats in Coquimbo (IV) region (Figs. 1, 12B, D).

Notes-The status of this taxon was provisionally recorded as insufficiently known and presumably extinct from the Limarí province and the Ovalle Common at Coquimbo region (Marticorena et al. 2001) based on the lack of records of
D. biloba in the region since 1948. During our expeditions in 2006 and 2008, six new populations of D. biloba subsp. coquimbana were discovered in this area (Figs. 1, 11A-C). These populations occupy dry stony habitats in calcareous outcrops and were generally in a healthy condition, but the number of individuals within each population barely reaches a few hundred and they are close to cultivated fields or found among pastures. The species should be considered as Vulnerable VU B2a, $b_{(i i+i i i+i v)}$ c (IUCN 2008), and ecologically similar sites should be explored to search for additional populations.

Representative Specimens Examined-CHILE. Coquimbo region (Region IV): Carretera de Ovalle a La Aguada, antes de Chalinga. $30^{\circ} 43.964^{\prime} \mathrm{S}, 71^{\circ} 22.836^{\prime} \mathrm{W}$, grietas de rocas calizas, 22 Aug 2006, SegarraMoragues and Pérez-Collazos R282234, R282235, R282245, and R282246 (JACA). Carretera de Ovalle a La Aguada, $30^{\circ} 43.906^{\prime} \mathrm{S} 71^{\circ} 22.794^{\prime} \mathrm{W}$, Cerro rodeado de cultivos y pastos; orient. S, en grietas calizas, 20 Aug 2008, Villar and Viruel R284619 (JACA). Carretera de Chalinga a La Aguada, $30^{\circ} 47.875^{\prime} \mathrm{S}, 71^{\circ} 27.056^{\prime} \mathrm{W}$, grietas de rocas calizas junto a la carretera, 22 Aug 2006, Segarra-Moragues and Pérez-Collazos R282247, R282248, R282249, R282250, and R282251 (JACA). Carretera de Parral de Quiles a San Pedro de Quiles, $30^{\circ} 57.630^{\prime} \mathrm{S}, 71^{\circ} 28.417^{\prime} \mathrm{W}$, grietas de rocas calizas junto a la carretera, 23 Aug 2006, Segarra-Moragues and Pérez-Collazos R282236, $R 282252$, and R282253 (JACA). Carretera de Queñén a Maqui de Quiles, $31^{\circ} 03.920^{\prime} \mathrm{S}, 71^{\circ} 31.534^{\prime} \mathrm{W}$, grietas de rocas calizas húmedas en barranco junto a la carretera, 23 Aug 2006, Segarra-Moragues and Pérez-Collazos R282233, and R282254 (JACA). Carretera de Los Vilos a Illapel, 31 $51.938^{\prime} \mathrm{S}$ $71^{\circ} 23.895^{\prime} \mathrm{W}$, ladera de pastos encima de la vía del ferrocarril en calizas, 19 Aug 2008, Villar and Viruel R284612, R284613, R284614, R284615, R284616 and $R 284617$ (JACA). Canela Alta, al otro lado del río Choapa, $31^{\circ} 23.249^{\prime} \mathrm{S}$ $71^{\circ} 24.975^{\prime} \mathrm{W}$, Ladera en exp. $\mathrm{S}$ al borde del río, suelo fértil y relat. fresco, 19 Aug 2008, Villar and Viruel R284618 (JACA).

2. Dioscorea humilis Colla, Memorie della Reale Accademia delle Scienze di Torino, 39: p. 12, tab. LI Fig. 2. 1836. Borderea humilis (Colla) Pax, in: Engler and Prantl, Die Natürlichen Pflanzenfamilien 2(5): 133. 1887. Epipetrum humile (Colla) Phil., Anales de la Universidad de Chile 21: 448. 1862.-TYPE: Chile: Valparaíso in sylvosis collinis loco dicto Las Tablas 7345 (holotype: TO-HG!).

Dioscorea pusilla Hook, Icones Plantarum 7, t.678. 1844.TYPE: Chile: La Plasilla near Valparaíso, 1832, Bridges, n. 166, (lectotype: K!, here designated).

Luzuriaga cordata Bertero, El Mercurio Chileno 15: 693. 1829. [Monocot.: Dioscor.], nom. utique rej. Viruel et al. (2009)— TYPE: Chile: Rancagua, May 1828, Bertero 394 (isotype: G-DC!).

Tubers irregularly shaped to globose, $2.5-3 \times 2.5 \mathrm{~cm}$, covered by roots. Annual aerial shoots herbaceous, single, trailing and branching at $0.4-8.5 \mathrm{~cm}$ from the tuber, up to $34 \mathrm{~cm}$ long. Leaves alternate, opposite or rarely whorled, petiolate; petioles (2.3-) $21.2(-128.0) \mathrm{mm}$ long, papillose. Papillae acute with striate periclinal walls; lamina (2.0-) $12.71(-29.0) \times(2.5-)$ $12.3(-33.0) \mathrm{mm}$, obovate, somewhat fleshy or not, leaf apex emarginate, mucronate; leaf margin entire or slightly papillose crenulate; leaves papillose, and sparsely covered with glandular hairs on both sides; papillae reddish or colorless, with stellate-densely reticulate periclinal walls, sometimes striate or smooth on abaxial side. Secondary venation marked or not. Inflorescences axillary. Male inflorescences shortly racemose to cymose and ephemeral. Male flowers pedicellate; pedicels (4-) 10.17 (-18) mm long. Female inflorescences axillary. Female flowers solitary, rarely $2-3$ per inflorescence, pedicellate; pedicel (3.0-) 11.7 (-32) mm long. Capsule pedunculate; peduncle spirally curled and papillose; papillae from peduncle acute with striate periclinal walls; globose (3.3-) $4.9(-7.0) \times$ (3.0-) $4.3(-5.8) \mathrm{mm}$ in size, widest near the middle, papillose 


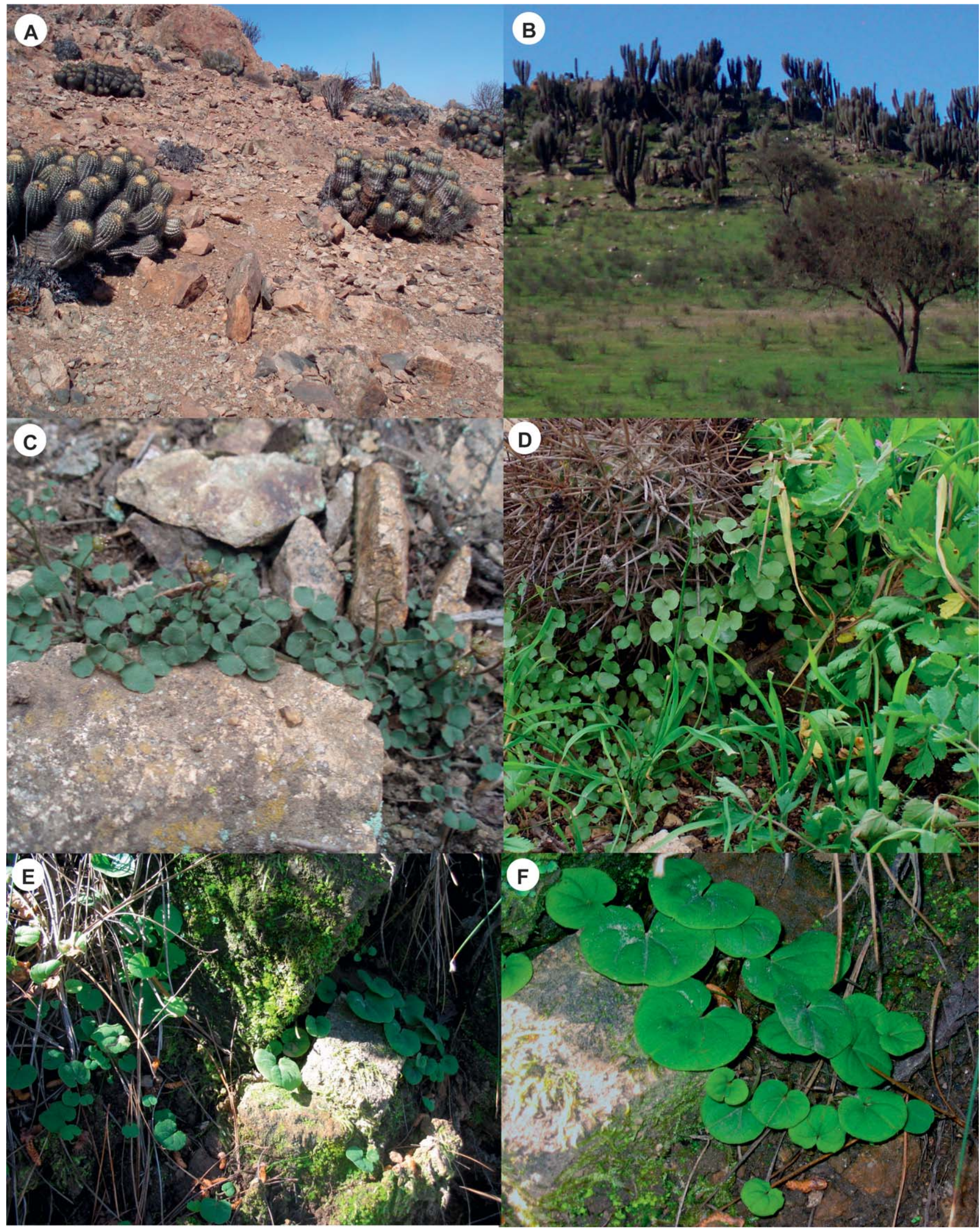

FIG. 12. Natural habitats and appearance of the Epipetrum group of Dioscorea taxa. A. Habitat of D. biloba subsp. biloba (Antofagasta, Taltal). B. Habitat of D. biloba subsp. coquimbana (Coquimbo, La Aguada). C. Male plant of D. biloba subsp. biloba. D. Individuals of D. biloba subsp. coquimbana growing on limestone rocks among cacti. E. Individuals of D. humilis subsp. polyanthes growing among limestone rocks (Maule, Constitución). F. Detail of D. humilis subsp. polyanthes showing the leaves without marked secondary veins. 
and glandulose; papillae with reticulate periclinal walls. Seeds ovoid and globose (1.0-) $2.0(-2.8) \times(0.8-) 1.5(-2) \mathrm{mm}$, brownish, wingless, with a small caruncle (0.1-) $0.26(-0.4) \mathrm{mm}$ long.

Two subspecies are recognized within this taxon.

\subsection{Dioscorea humilis Colla subsp. HumiLis.}

Tubers $3 \times 2.5 \mathrm{~cm}$. Leaves alternate, opposite or rarely whorled, petiolate; petioles (2.3-) $20.3(-128) \mathrm{mm}$ long. Lamina (2-) $10.8(-29) \times(2.5-) 12.3(-33) \mathrm{mm}$, membranous, not fleshy; papillae with stellate-densely reticulate periclinal walls. Secondary venation marked giving the abaxial side of the leaf a grooved to reticulate appearance. Pedicels of male flowers (4-) $10.17(-18) \mathrm{mm}$ long. Pedicel of female flowers (3-) 11.5 (-32) mm long. Capsule (3.3-) $4.4(-7) \times(3-) 3.7$ (-5.6) $\mathrm{mm}$. Seeds (1-) $1.97(-2.8) \times(0.8-) 1.4(-2) \mathrm{mm}$, with a small caruncle (0.1-) $0.24(-0.4) \mathrm{mm}$ long. Figure 10.

Phenology-Flowering from June to August.

Habitat and Distribution-Wet limestone rocks and crevices in shady habitats, more rarely on sandy soil, from Valparaíso (V) to Bío-Bío (VIII) regions (Figs. 1 and 13).

Notes-Dioscorea humilis subsp. humilis is the most widespread taxon of the Epipetrum group. Its distributional range spans five Chilean regions from $32^{\circ} \mathrm{S}$ to $37^{\circ} \mathrm{S}$ (Fig. 1). Individuals are generally abundant within populations, sometimes numbering in the thousands. This taxon does not require specific conservation policies, neither should it be considered as threatened.

Representative Specimens Examined-CHILE. Región de Valparaíso (Region V): Catapilco, rincón de La Mestiza, 32 32.556'S, $71^{\circ} 17.629^{\prime} \mathrm{W}$, taludes y grietas de rocas calizas, 21 Aug 2006, Segarra-Moragues and Pérez-Collazos R282255, R282256, R282257, R282285, and R282259 (JACA). La Plasilla, near Valparaíso, 1832, Bridges 166 (K). Valparaíso, Jul 1830, Bertero 1119 (G). Valparaíso, 1867, Cuming 686 (K). Near Valparaíso, warm valleys, 4 jul 1867, Mathews s. n. (K). Quillota, 1829, Bertero 1119 (G). Quillota, Bertero 1119 (G). Región Metropolitana (M region): Granizo, Parque Nacional de La Campana, sector Granizo, puente de La Troya, $32^{\circ} 59.089^{\prime} \mathrm{S}, 7^{\circ} 08.296^{\prime} \mathrm{W}$, taludes húmedos, 16 Aug 2006, SegarraMoragues and Pérez-Collazos R282260, and R282261 (JACA). Parque Nacional de La Campana, sector Cajón Grande, $33^{\circ} 00.101^{\prime} \mathrm{S}, 71^{\circ} 07.891^{\prime} \mathrm{W}$, taludes húmedos junto a la pista forestal, 16 Aug 2006, Segarra-Moragues and Pérez-Collazos R282244 (JACA). Parque Nacional de La Campana, Aug 1985, Teillier 1888 (HDCV). Carretera a Til Til, Entrada a Parcelación de El tranque, $33^{\circ} 08.679^{\prime} \mathrm{S}, 70^{\circ} 52.580^{\prime} \mathrm{W}$, grietas de rocas calizas junto a la pista forestal, 15 Aug 2006, Segarra-Moragues and Pérez-Collazos R282262, and R282263 (JACA). Carretera de Til Til a Limache, Desvío a La Vega por el Camarico, $33^{\circ} 03.472^{\prime} \mathrm{S}, 71^{\circ} 02.953^{\prime} \mathrm{W}$, taludes húmedos junto a la carretera, 15 Aug 2006, Segarra-Moragues and Pérez-Collazos R282237, and R282264 (JACA). Santiago de Chile, Cerro Manquehue, barranco subiendo desde Agua del Palo, $33^{\circ} 21.838^{\prime} \mathrm{S}, 70^{\circ} 34.949^{\prime} \mathrm{W}$, grietas de roca caliza en zonas húmedas, 13 Aug 2006, Segarra-Moragues and Pérez-Collazos R282265 (JACA). Santiago de Chile, Cerro de Renca, $33^{\circ} 23.719^{\prime} \mathrm{S}, 70^{\circ} 42.649^{\prime} \mathrm{W}$, grietas de roca caliza desde la parte media del cerro hasta cerca de la cima, 12 Aug 2006, Segarra-Moragues and Pérez-Collazos R282266 (JACA). Maipo, Cerro Cantillana, de Rague a Pabellón, 3351.180'S, $70^{\circ} 58.742^{\prime} \mathrm{W}$, taludes húmedos junto a la pista forestal, 14 Aug 2006, Segarra-Moragues and Pérez-Collazos R282267, and R282268 (JACA). Maipo, Cerros de Acúleo, $33^{\circ} 50.074^{\prime} \mathrm{S}, 70^{\circ} 51.234^{\prime} \mathrm{W}$, taludes húmedos y grietas de rocas calizas junto a la pista forestal, 14 Aug 2006, Segarra-Moragues and Pérez-Collazos $R 282238, R 282239, R 282269$, and R282270 (JACA). Cerros de Acúleo, entre rocas, en la ladera de los cerros, 16 Oct 1969, Navas 3433 (B). Región de O'Higgins (Region VI): Rancagua, 1833, Bertero 394 (G). Rancagua, May 1828, Bertero 394 (G). Yaquil, Sept 1862, Philippi 047238 (SGO). Carretera de Rancagua a Doñihue, $34^{\circ} 11.470^{\prime} \mathrm{S}, 70^{\circ} 50.656^{\prime} \mathrm{W}$, taludes y rocas calizas húmedas junto a la carretera, 20 Aug 2006, Segarra-Moragues and Pérez-Collazos R282271 (JACA). Carretera de Coya a Pangal, 34¹2.054'S, $70^{\circ} 30.973^{\prime} \mathrm{W}$, taludes y rocas calizas húmedas, 20 Aug 2006, SegarraMoragues and Pérez-Collazos R282272 (JACA). Carretera de San Fernando a Tinguiririca, $34^{\circ} 40.450^{\prime} \mathrm{S}, 70^{\circ} 52.940^{\prime} \mathrm{W}$, taludes y rocas calizas húmedas junto a la pista forestal de La Rufina, 19 Aug 2006, Segarra-Moragues and Pérez-Collazos R282240, R282241, R282242, and R282243 (JACA). Región del Maule (Region VII): Carretera de Curicó hacia Sagrada Familia, $35^{\circ} 03.050^{\prime} \mathrm{S}, 71^{\circ} 31.054^{\prime} \mathrm{W}$, taludes y roquedos húmedos junto a la carretera, 19 Aug 2006, Segarra-Moragues and Pérez-Collazos R282273, 282274, R282275, R282276, and R282277 (JACA). Región Bio-Bio (Region VIII): Entre Yumbel y Monteáguila, $37^{\circ} 05.006^{\prime} \mathrm{S}, 72^{\circ} 28.768^{\prime} \mathrm{W}$, taludes arenosos húmedos junto a la carretera, 17 Aug 2006, Segarra-Moragues and PérezCollazos R282278 (JACA).

2.2. Dioscorea humilis Colla subsp. polyanthes (F. Phil.) Viruel, Segarra-Moragues \& Villar, comb. et stat nov.Epipetrum polyanthes F. Phil., in: R.A. Phil., Anales de la Universidad de Chile 93: 22-23. 1896. Dioscorea polyanthes (F. Phil.) Caddick \& Wilkin, Taxon 51: 112. 2002.-TYPE: CHILE. "prope Constitución mense Mayo 1892 indefessus Dr. Carlos Reiche detexit", 038160 (holotype: SGO!).

Tubers $2.5 \times 2.5 \mathrm{~cm}$. Annual aerial shoots branching at 2-5 $\mathrm{cm}$ from the tuber, up to $28 \mathrm{~cm}$ long. Leaves alternate; petioles (10-) 29.3 (-90) mm long. Lamina (5.7-) $13.98(-24) \times$ (6.8-) $16.15(-28) \mathrm{mm}$, somewhat fleshy; papillae of adaxial side with reticulate periclinal walls, and those of abaxial side with striate or smooth periclinal walls. Secondary venation not marked. Pedicel of male flowers $11 \mathrm{~mm}$ long. Pedicel of female flowers (3.5-) 12 (-30) mm long. Capsule (4.3-) 5.24 $(-6.5) \times(3-) 4.24(-5.8) \mathrm{mm}$. Seeds (1.4-) $2(-2.2) \times(1.2-) 1.8$ $(-2) \mathrm{mm}$, with a small caruncle $(0.15-) 0.3(-0.4) \mathrm{mm}$ long. Figure 11.

Phenology-Flowering from June to July.

Habitat and distribution-Wet limestone rocks and crevices and shady places in pine forests in the Maule (VII) region, near Constitución (Figs. 1, 12E, F).

Notes-The epithet polyanthes refers to the apparently more prolific male inflorescences of this taxon compared to those of $D$. humilis subsp. humilis. This trait has been probably misinterpreted because both subspecies produce a similar number of male inflorescences. The confusion may be due to the different times of collection of the respective type specimens. Male inflorescences in both subspecies remain for only short periods on the plant as male flowers senesce rapidly when the pedicels break, and the inflorescences soon disappear. The type of Dioscorea humilis subsp. polyanthes was collected earlier in the growing season, when male inflorescences were just developing (SGO 038160), whereas D. humilis subsp. humilis may have been collected later in its growing season, when male inflorescences were disappearing. This could explain the higher number of male flowers recorded in D. humilis subsp. polyanthes than in D. humilis subsp. humilis. Further support for this hypothesis is that capsules were never described for subsp. polyanthes, which would be consistent with collection of the material at an earlier stage of development. In recent work produced for the Flora of Chile (www.chlorischile.cl/ Monocotiledoneas/epipetrumgen.htm), the differentiation between subspp. polyanthes and humilis is mainly based on the supposed presence of reddish papillae in the leaves of the latter and the absence of papillae in the former. Such differences were not reported in the original description of $D$. polyanthes, which was described as papillose. As shown here, both taxa have similar papillae (Fig. 3) that could have passed undetected on old herbarium specimens.

Dioscorea humilis subsp. polyanthes is the rarest taxon of the Epipetrum group and is poorly represented in herbaria. It is currently known from only two critically small populations near Constitución (Maule Region) that barely sum up 150 reproductive individuals. They inhabit pine forests that are intensively exploited for timber, constituting a further threat to the populations due to habitat destruction. Given 


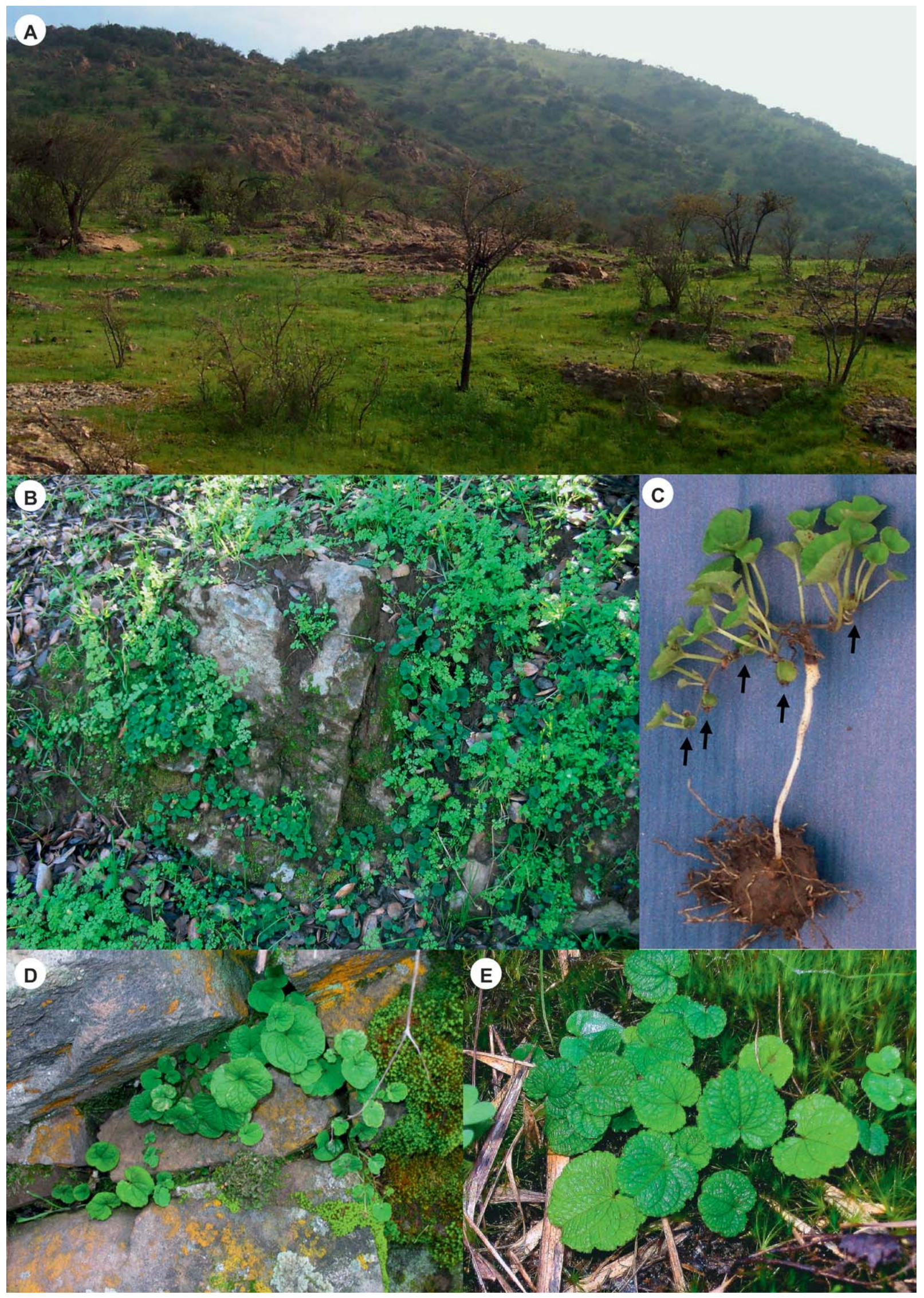

FIG. 13. Natural habitats and appearance of Dioscorea humilis subsp. humilis. A. Habitat of the species in sclerophyllous open wood (Metropolitan region, Til-Til). B. Group of individuals growing on wet limestone rocks (Metropolitan region, Cerros de Acúleo). C. Detail of a female individual showing the tuber covered with roots and developing fruits (arrows). D-E. Individuals growing among shaded limestone rocks and mosses showing the leaves with marked secondary veins (reticulate appearance). 
its highly restricted distribution and the significant threats to its survival, $D$. humilis subsp. polyanthes should be considered a critically endangered taxon CR B1a, $\mathrm{b}_{(\mathrm{i}+\mathrm{ii}+\mathrm{iv})^{\prime}}, \mathrm{B} 2 \mathrm{a}, \mathrm{b}_{(\mathrm{i}+\mathrm{ii}+\mathrm{iv})^{\prime}}$ C2 $\mathrm{a}_{(\mathrm{i})}, \mathrm{E}$ (IUCN 2008), and habitat protection is an immediate necessity.

Representative Specimens Examined-CHILE. Maule region (Region VII): Constitución, pasando el puente del río Maule en dirección a Putú, $35^{\circ} 20.094^{\prime} \mathrm{S}, 72^{\circ} 23.286^{\prime} \mathrm{W}$, taludes húmedos junto a la carretera, 18 Aug 2006, Segarra-Moragues and Pérez-Collazos R282231, and R282232 (JACA). Constitución a San Javier, $35^{\circ} 26.401^{\prime} \mathrm{S}, 72^{\circ} 20.004^{\prime} \mathrm{W}$, taludes húmedos en un pinar junto a la carretera, 18 Aug 2006, Segarra-Moragues and PérezCollazos R282230 (JACA).

Acknowledgments. We are indebted to Associate Editor G. M. Plunkett, to reviewers L. Raz and P. Wilkin, and to C. A. Stace and J. Müller for their valuable comments on an earlier version of the manuscript; to M. Muñoz, C. Marticorena, and A. Pistarino for providing herbarium data from SGO, CONC, and TO, respectively; the staff of CONAF (I. Benoit, J. Meza, and C. Díaz-Gutiérrez) for providing permission to collect in $\mathrm{La}$ Campana National Park; to E. Navarro and M. T. Mínguez-Hernández for assistance with SEM; to M. Laínz for revising the Latin diagnosis of D. biloba subsp. coquimbana; and to J. L. Castillo for figures 8-11. This study has been supported by a Fundación BBVA BIOCON 05-093/06 project grant. J. G. Segarra-Moragues was supported by an Agencia Aragonesa para la Investigación y el Desarrollo (ARAID) postdoctoral contract; J. Viruel and E. Pérez-Collazos were supported by a doctoral and postdoctoral grants from the Fundación BBVA project, respectively.

\section{Literature Cited}

Anderson, T. W. 1996. R. A. Fisher and Multivariate Analysis. Statistical Science 11: 20-34.

Baum, B. R. 1989. Theory and practice of botanical classification - cladistics, phenetics and classical approaches - critical summary - Botanical Systematics in 1987. Plant Systematics and Evolution 166: 197-210.

Bertero, C. G. 1829. Lista de plantas que han sido observadas en Chile por el Dr. Bertero en 1828. El Mercurio Chileno 12: 551-564.

Bousalem, M., G. Arnau, I. Hochu, R. Arnolin, V. Viader, S. Santoni, and J. David. 2006. Microsatellite segregation analysis and cytogenetic evidence for tetrasomic inheritance in the American yam Dioscorea trifida and a new basic chromosome number in the Dioscoreae. Theoretical and Applied Genetics 113: 439-451.

Bruni, A., B. Tosi, and P. Modenesi. 1987. Morphology and secretion of glandular trichomes in Tamus communis. Nordic Journal of Botany 7: 79-84.

Burkill,I. H. 1960. The organography and the evolution of Dioscoreaceae, the family of the yams. Botanical Journal of the Linnean Society 56: 319-412.

Caddick, L. R., C. A. Furness, K. L. Stobart, and P. J. Rudall. 1998. Microsporogenesis and pollen morphology in Dioscoreales and allied taxa. Grana 37: 321-336.

Caddick, L. R., P. J. Rudall, P. Wilkin, T. A. J. Hedderson, and M. W. Chase. 2002a. Phylogenetics of Dioscoreales based on combined analyses of morphological and molecular data. Botanical Journal of the Linnean Society 138: 123-144.

Caddick, L. R., P. Wilkin, P. J. Rudall, T. A. J. Hedderson, and M. W. Chase. 2002b. Yams reclassified: a recircumscription of Dioscoreaceae and Dioscoreales. Taxon 51: 103-114.

Catalán, P., J. G. Segarra-Moragues, M. Palop-Esteban, C. Moreno, and F. González-Candelas. 2006. A Bayesian approach for discriminating among alternative inheritance hypotheses in plant polyploids: the allotetraploid origin of genus Borderea (Dioscoreaceae). Genetics 172: 1939-1953.

Christensen, I. K. 1984. The morphological variation of some Crataegus populations (Rosaceae) in Greece and Yugoslavia. Nordic Journal of Botany 4: 585-595.

Colla, L. A. 1836. Plantae rariores in regionibus Chilensibus a clarisimo m. d. Bertero nuper detectae et ab A. Colla in lucem editae. Memorie della Reale Accademia delle Scienze di Torino 39: 9-14.

Fisher, R. A. 1936. The use of multiple measurements in taxonomic problems. Annals of Eugenics 7: 179-188.

Govaerts, R., P. Wilkin, and R. M. K. Saunders. 2007. World checklist of Dioscoreales: yams and their allies. Kew: Kew Publishing.

Hechenleitner, V. P., M. F. Gardner, P. I. Thomas, C. Echeverría, B. Escobar, P. Brownless, and A. C. Martínez. 2005. Plantas amenazadas del CentroSur de Chile. Distribución, conservación y propagación. Valdivia: Universidad Austral de Chile y Real Jardín Botánico de Edimburgo.
Heslot, H. 1953. Le nombre chromosomique des Dioscoréacées pyrénéennes et leur rattachement au genre Borderea Miégeville. Comptes Rendus à l'Académie des Sciences de Paris 237: 433-434.

IUCN. 2008. Red list categories and criteria (version 3.1). Available at: http://www.iucnredlist.org/.

Knuth, R. 1924. Dioscoreaceae. Pp. 1-387 in Das Pflanzenreich 87(IV), ed. H. G. A. Engler. Leipzig: W. Engelmann.

Koutecky, P. 2007. Morphological and ploidy level variation of Centaurea phrygia agg. (Asteraceae) in the Czech Republic, Slovakia and Ukraine. Folia Geobotanica 42: 77-102.

Marticorena, C., F. A. Squeo, G. Arancio, and M. Muñoz. 2001. Catálogo de la flora vascular de la IV Región de Coquimbo. Pp. 105-142 in Libro Rojo de la flora nativa y de los sitios prioritarios para su conservación: Región de Coquimbo, eds. F. A. Squeo, G. Arancio, and J. R. Gutiérrez. La Serena, Chile: Ediciones de la Universidad de La Serena.

Matuda, E. 1961. Nuevas plantas de México. Anales del Instituto de Biología de la Universidad Nacional Autónoma de México 32: 143-147.

McCauley, R. A. and H. E. Ballard. 2007. Systematics of North American Froelichia (Amaranthaceae subfam. Gomphrenoideae) I: Identification of consistent morphological variation and segregation of species complexes. Brittonia 59: 255-274.

Meurman, O. 1925. The chromosome behaviour of some dioecious plants and their relatives with special reference to sex chromosomes. Societas Scientiarum Fennica. Commentationes Biologicae 2: 1-105.

Milne-Redhead, E. 1963. Dioscoreaceae. Kew Bulletin 17: 177-179.

Oja, T. and J. Paal. 2006. Multivariate analysis of morphological variation among closely related species Bromus japonicus, B. squarrosus and B. arvensis (Poaceae) in comparison with isozyme evidences. Nordic Journal of Botany 24: 691-702.

Orr, M. 1926. On the secretory organs of the Dioscoreaceae. Notes from the Royal Botanic Garden of Edinburgh 15: 133-146.

Pax, F. A. 1887. Dioscoreaceae. Pp. 133-137 in Die Natürlichen Pflanzenfamilien 2(5), eds. H. G. A. Engler and K. A. E. Prantl. Leipzig: Verlag von Wilhelm Engelman.

Philippi, R. A. 1862. Descripción de unas plantas nuevas, recogidas en el verano pasado en la provincia del Maule y Chillan por Don Jerman Volckmann. Anales de la Universidad de Chile 21: 442-450.

Philippi, R. A. 1864. Plantarum novarum Chilensiam centuriae, inclusis quihusdam Mendocis et Patagonicis. Linnaea 33: 1-308.

Philippi, R. A. 1892. Epipetrum bilobum Ph. Anales del Museo Nacional de Santiago de Chile 11, table 3. fig. 1.

Philippi, R. A. 1896. Plantas nuevas Chilenas, de las familias que corresponden al tomo VI de la obra de Gay. Anales de la Universidad de Chile 93: 5-24.

Pimentel, M. and E. Sahuquillo. 2007. Infraspecific variation and phylogeography of the high-polyploid Iberian endemic Anthoxanthum amarum Brot. (Poaceae; Pooideae) assessed by random amplified polymorphic DNA markers (RAPDs) and morphology. Botanical Journal of the Linnean Society 155: 179-192.

Reiche, K. 1908. Zur kenntnis der Dioscoreaceen-gattung Epipetrum Phil. Botanische Jahrbucher für Systematik, Pflanzengeschichte und Pflanzengeographie 42: 178-190.

Robart, B. W. 2005. Morphological diversification and taxonomy among the varieties of Pedicularis bracteosa Benth. (Orobanchaceae). Systematic Botany 30: 644-656.

Scarcelli, N., O. Dainou, C. Agbangla, S. Tostain, and J. L. Pham. 2005. Segregation patterns of isozyme loci and microsatellite markers show the diploidy of African yam Dioscorea rotundata $(2 n=40)$. Theoretical and Applied Genetics 111: 226-232.

Schols, P., C. A. Furness, P. Wilkin, S. Huysmans, and E. Smets. 2001. Morphology of pollen and orbicules in some Dioscorea (Dioscoreaceae) species and its systematic implications. Botanical Journal of the Linnean Society 136: 295-311.

Schols, P., C. A. Furness, P. Wilkin, E. Smets, V. Cielen, and S. Huysmans. 2003. Pollen morphology of Dioscorea (Dioscoreaceae) and its relation to systematics. Botanical Journal of the Linnean Society 143 375-390.

Schols, P., P. Wilkin, C. A. Furness, S. Huysmans, and E. Smets. 2005. Pollen evolution in Yams (Dioscorea: Dioscoreaceae). Systematic Botany 30: 750-758.

Segarra, J. G. and P. Catalán. 2005. Borderea Miégeville. Pp. 11-14 in: Flora Iberica vol. 21, eds. C. Aedo and A. Herrero. Madrid: Real Jardín Botánico de Madrid-C. S. I. C.

Shapiro, S. S. and M. B. Wilk. 1965. An analysis of variance test for normality (complete samples). Biometrika 52: 591-611.

Smith, B. W. 1937. Notes on the cytology and distribution of the Dioscoreaceae. Bulletin of the Torrey Botanical Club 64: 189-197. 
Téllez-Valdés, O. and P. Dávila-Aranda. 1998. Nanarepenta juxtlahuacensis (Dioscoreaceae), una nueva especie de Oaxaca, México. Novon 8: 210-214.

Torrecilla, P., J. A. L. Rodríguez, D. Stancik, and P. Catalán. 2003. Systematics of Festuca L. sects. Eskia Willk., Pseudatropis Kriv., Amphigenes (Janka) Tzvel., Pseudoscariosa Kriv. and Scariosae Hack. based on analysis of morphological characters and DNA sequences. Plant Systematics and Evolution 239: 113-139.

Viruel, J., J. G. Segarra-Moragues, E. Pérez-Collazos, L. Villar, and P. Catalán. 2008. The diploid nature of the Chilean Epipetrum and a new base number in the Dioscoreaceae. New Zealand Journal of Botany 46: 327-339.
Viruel, J., J. G. Segarra-Moragues, E. Pérez-Collazos, P. Catalán, L. Villar Z. Díaz-Lifante, B. Valdés, and J. Müller. 2009. Proposal to reject the name Luzuriaga cordata (Dioscoreaceae). Taxon 58: 1007.

Visanta-Vinacua, B. 1998. Análisis estadístico con SPSS para Windows. Madrid: McGraw-Hill. Interamericana de España.

Wilkin, P., P. Schols, M. W. Chase, C. Kongkanda, C. A. Furness, S. Huysmans, F. Rakotonasolo, E. Smets, and C. Thapyai. 2005. A plastid gene phylogeny of the yam genus, Dioscorea: roots, fruits and Madagascar. Systematic Botany 30: 736-749.

Wilks, S. S. 1932. Certain generalizations in the analysis of variance. Biometrika 24: 471-494. 